\title{
Synthesis of Ti3AuC2, Ti3Au2C2 and Ti3IrC2 by noble metal substitution reaction in Ti3SiC2 for high-temperature-stable Ohmic contacts to SiC
}

Hossein Fashandi, Martin Dahlqvist, J un Lu, J ustinas Palisaitis, Sergey Simak, Igor Abrikosov, J ohanna Rosén, Lars Hultman, Mike Andersson, Anita Lloyd Spetz and Per Eklund

The self-archived version of this journal article is available at Linköping University Institutional Repository (DiVA):

http:/ / urn.kb.se/ resolve?urn=urn:nbn:se:liu:diva-139912

N.B.: When citing this work, cite the original publication.

Fashandi, H., Dahlqvist, M., Lu, J., Palisaitis, J., Simak, S., Abrikosov, I., Rosén, J ., Hultman, L., Andersson, M., Lloyd Spetz, A., Eklund, P., (2017), Synthesis of Ti3AuC2, Ti3Au2C2 and Ti3IrC2 by noble metal substitution reaction in Ti3SiC2 for high-temperature-stable Ohmic contacts to $\mathrm{SiC}$,

Nature Materials, 16(8), 814-818. https:// doi.org/ 10.1038/ NMAT4896

Original publication available at:

https:/ / doi.org/ 10.1038/NMAT4896

Copyright: Nature Publishing Group

http:// www.nature.com/ 
22
Synthesis of $\mathrm{Ti}_{3} \mathrm{AuC}_{2}, \mathrm{Ti}_{3} \mathrm{Au}_{2} \mathrm{C}_{2}$ and $\mathrm{Ti}_{3} \mathrm{IrC}_{2}$ by noble-metal substitution reaction in $\mathrm{Ti}_{3} \mathrm{SiC}_{2}$ for high-temperature-stable ohmic contacts to $\mathrm{SiC}$

Hossein Fashandi, Martin Dahlqvist, Jun Lu, Justinas Palisaitis, Sergei I. Simak, Igor A. Abrikosov, Johanna Rosen, Lars Hultman, Mike Andersson*, Anita Lloyd Spetz , and Per Eklund*

Department of Physics, Chemistry, and Biology (IFM), Linköping University, SE-581 83

Linköping, Sweden

KEYWORDS: Layered phases, noble metals, MAX phase ohmic contacts, oxidation resistance

14

(1)

7

8

9

0

3

4

25

* Corresponding authors. E-mail: perek@ifm.liu.se (P. Eklund) spetz@ifm.liu.se (A. Lloyd-Spetz) mikan@ifm.liu.se

(M. Andersson) 
The large class of layered ceramics encompasses both van der Waals (vdW) and nonvdW solids. While intercalation of noble metals in vdW solids is known, formation of compounds by incorporation of noble-metal layers in non-vdW layered solids is largely unexplored. Here, we show formation of $\mathrm{Ti}_{3} A u C_{2}$ and $\mathrm{Ti}_{3} \mathrm{Au}_{2} \mathrm{C}_{2}$ phases with up to $31 \%$ lattice swelling by a substitutional solid-state reaction of $\mathrm{Au}$ into $\mathrm{Ti}_{3} \mathrm{SiC}_{2}$ single-crystal thin films with simultaneous out-diffusion of $\mathrm{Si}$. $\mathrm{Ti}_{3} \mathrm{IrC}_{2}$ is subsequently produced by a substitution reaction of $\mathrm{Ir}$ for $\mathrm{Au}$ in $\mathrm{Ti}_{3} \mathrm{Au}_{2} \mathrm{C}_{2}$. These phases form ohmic electrical contacts to $\mathrm{SiC}$ and remain stable after $1000 \mathrm{~h}$ of aging at $600{ }^{\circ} \mathrm{C}$ in air. The present results, by combined analytical electron-microscopy and $a b$-initio calculations, open avenues for processing of noble-metal-containing layered ceramics that have not been synthesized from elemental sources, along with tunable properties such as stable electrical contacts for high-temperature power electronics or gas sensors.

$\mathrm{M}_{\mathrm{n}+1} \mathrm{AX} \mathrm{X}_{\mathrm{n}}$ phases are a family of inherently nanolaminated ternary ceramics with more than 70 members. In this notation, $M$ is an early transition metal, $A$ is an element from groups $12-16$, $\mathrm{X}$ is carbon or nitrogen, and $\mathrm{n}=1-3$ and possibly higher ${ }^{1,2}$. Structurally, they consist of $\mathrm{M}_{\mathrm{n}+1} \mathrm{X}_{\mathrm{n}}$ sheets sandwiched in between one-atom-thick A-layers. The latter can be wetchemically removed or thermally desorbed from a $M_{n+1} A X_{n}$ phase resulting in the formation of two-dimensional (2D) $M_{n+1} X_{n}$ sheets known as MXene ${ }^{3,4}$. MXenes are a novel class of 2D materials $^{5-8}$ that are both hydrophilic and conductive, exhibit high volumetric capacitance, and allow for intercalation of a range of species ${ }^{11,12}$. The intercalant then resides in the laminar voids between MXene layers. This is in contrast to their parent $M_{n+1} A X_{n}$ phases and motivates the present study for synthesizing noble-metal-containing layered ceramics by an ordered replacement of the A-layer crystal planes; from Si-planes to $\mathrm{Au}-, \mathrm{Au}_{2^{-}}$or Ir-planes. Generally, $M_{n+1} A X_{n}$ phases possess a mixed nature of metal/ceramic properties as resistance to wear and thermal shock, together with high thermal and electrical conductivities which make them viable candidate materials for harsh-environment applications such as ohmic contacts for high-temperature semiconductor electronics ${ }^{2}$. For such applications, however, high-temperature-induced surface oxidation and destructive interdiffusion between adjacent metallic phases forming the contacts are the main reasons for failure ${ }^{13}$. Replacement of the Alayer with noble metals to form e.g., $\mathrm{Ti}_{3} \mathrm{AuC}_{2}$ can thus potentially modify $\mathrm{M}_{\mathrm{n}+1} \mathrm{AX}_{\mathrm{n}}$ phases to withstand harsh oxidizing environments.

Here, we report substitution of $\mathrm{Au}$ and $\mathrm{Ir}$ in thin films of the $\mathrm{M}_{\mathrm{n}+1} \mathrm{AX}_{\mathrm{n}}$ phase $\mathrm{Ti}_{3} \mathrm{SiC}_{2}$ through solid-state diffusion processes at $\sim 650{ }^{\circ} \mathrm{C}$. Fully replacing $\mathrm{Si}$ with $\mathrm{Au}$, we show the synthesis of the novel phases $\mathrm{Ti}_{3} A u C_{2}$, and $\mathrm{Ti}_{3} \mathrm{Au}_{2} \mathrm{C}_{2}$ as well as $\mathrm{Ti}_{3} \mathrm{IrC}_{2}$ by replacing $\mathrm{Au}$ with $\mathrm{Ir}$ in $\mathrm{Ti}_{3} \mathrm{Au}_{2} \mathrm{C}_{2}$. These phases exhibit long-term high-temperature structural stability without $\mathrm{Au}$ out-diffusion, as well as ohmicity to silicon carbide ( $\mathrm{SiC}$ ), yielding high-temperaturecompatible $\mathrm{SiC}$ ohmic contacts. Based on $\mathrm{Ti}_{3} \mathrm{AuC}_{2}$ and an oxygen-barrier capping layer of $\mathrm{Au} /$ Iridium oxide $\left(\mathrm{IrO}_{\mathrm{x}}\right)$ we designed an ohmic contact which survived a 1000-h annealing at $600{ }^{\circ} \mathrm{C}$ room-air with intact ohmicity and structure. These results have broad implications since they demonstrate the ability to selectively replace the A layers with noble metals in layered transition metal carbides.

Initially, 60 -nm-thick ohmic $\mathrm{Ti}_{3} \mathrm{SiC}_{2}$ films were grown on $4 \mathrm{H}-\mathrm{SiC}$ by a single-step growth method, which is based on concurrent solid state reaction of sputter deposited $\mathrm{Ti}$ on $\mathrm{SiC}^{14}$. Next, we sputter-deposited $200 \mathrm{~nm}$ of $\mathrm{Au}$ on the surface of $\mathrm{Ti}_{3} \mathrm{SiC}_{2}$, as schematically 
illustrated in Figure 1(a). Figure 1(b) is a scanning transmission electron microscopy (STEM) image from the $\mathrm{Ti}_{3} \mathrm{SiC}_{2}$ layer of this sample showing $\mathrm{M}_{3} \mathrm{X}_{2}\left(\mathrm{Ti}_{3} \mathrm{C}_{2}\right)$ sheets separated by Alayers ( $\mathrm{Si}$ ), typical of $\mathrm{M}_{3} \mathrm{AX}_{2}$ phases ${ }^{2}$. The Au-covered $\mathrm{Ti}_{3} \mathrm{SiC}_{2}$ samples were then annealed for $12 \mathrm{~h}$ at $670{ }^{\circ} \mathrm{C}$ in $\mathrm{N}_{2}$ gas atmosphere to avoid oxidation. Figure 1 (c) is an STEM image of the same sample, after the annealing procedure, at the region where $\mathrm{Ti}_{3} \mathrm{SiC}_{2}$ was initially present. The brightness of a species in STEM is proportional to its mass. The A-layers separating the $\mathrm{Ti}_{3} \mathrm{C}_{2}$ sheets in Figure 1(c) are much brighter than Si planes in Figure 1 (b) and are thus composed of the much heavier element $\mathrm{Au}$, which has diffused in between the $\mathrm{Ti}_{3} \mathrm{C}_{2}$ sheets of $\mathrm{Ti}_{3} \mathrm{SiC}_{2}$. Figure 1(d) is an energy dispersive X-ray spectroscopy (EDX) line-scan of $\mathrm{Ti}-\mathrm{K} \alpha$ and Au-M $\alpha$ signals along the arrow in Figure 1(c). The maximum of one elemental signal matches the minimum of the other, unambiguously identifying the inserted element in $\mathrm{Ti}_{3} \mathrm{SiC}_{2}$ as $\mathrm{Au}$. Regions of the $\mathrm{Ti}_{3} \mathrm{SiC}_{2}$ layer close to the substrate and thus far from the $\mathrm{Au}$ source exhibit incomplete Au layers. Figure 1(e) is a STEM image and the related EDX map from such a location, showing that there is a distinct reaction front advancing step-wise over layers into the $\mathrm{Ti}_{3} \mathrm{SiC}_{2}$. Refer to the supplementary material for a STEM movie (described in Supplementary text section S.14) showing the process in situ.

The $\mathrm{Si}$ was found to have diffused out of the annealed $\mathrm{Ti}_{3} \mathrm{SiC}_{2}$ using scanning electron microscopy (SEM)/EDX, (see S1). A high oxygen content of the Si-rich regions and the fact that no X-ray diffraction (XRD) peaks related to Si-containing phases were observed in the annealed samples, indicate the formation of amorphous $\mathrm{SiO}_{2}$ on the sample surfaces while they were stored in room-air after the annealing procedure and prior to the SEM/EDX study. The Si content of the A layers in the novel structure is negligible, based on EDX results, and it can thus be described as $\mathrm{Ti}_{3} \mathrm{AuC}_{2}$. Figures $1(\mathrm{f})$ and $1(\mathrm{~g})$ show $\mathrm{STEM}$ of $\mathrm{Ti}_{3} \mathrm{AuC}_{2}$ with the beam aligned along the two zone axes [11 $\overline{2} 0]$ and [1 $1 \overline{1} 00]$, respectively. The atomic positions match those of a $\mathrm{M}_{3} \mathrm{AX}_{2}$ phase. Figure 1(h) shows X-ray diffractograms of the sample illustrated in Figure 1(a) before and after the annealing. The 0001 peaks of $\mathrm{Ti}_{3} \mathrm{SiC}_{2}$ have shifted towards lower angles as a result of the $\mathrm{Au}$ insertion with its larger atomic size. The intercalation thus results in an increased $c$ lattice parameter from $17.63 \AA$ for $\mathrm{Ti}_{3} \mathrm{SiC}_{2}$ to 18.56 $\AA$ in $\mathrm{Ti}_{3} \mathrm{AuC}_{2}$, i.e., by $5.3 \%$. The residual peaks of $\mathrm{Ti}_{3} \mathrm{SiC}_{2}$ could be further removed by annealing at higher temperatures, e.g., at $700{ }^{\circ} \mathrm{C}$, see $\mathrm{S} 4 . \mathrm{Ti}_{3} \mathrm{AuC}_{2}$ with the space group of $\mathrm{P}_{3} / \mathrm{mmc}(194)$ has the same crystal structure as $\mathrm{Ti}_{3} \mathrm{SiC}_{2}$.

With density functional theory (DFT), we studied the formation enthalpy of the $\mathrm{Ti}_{3} \mathrm{AuC}_{2}$ phase by comparing its $0-\mathrm{K}$ energy to the most competing phases in Ti-Au-C system, (see S2 for the computations). Included competing phases are based on experimental phase diagrams and what is present in similar systems, see S3 and S6. These calculations showed that $\mathrm{Ti}_{3} \mathrm{AuC}_{2}$ has negative formation enthalpy when compared to the most competing phases, indicating its thermodynamic stability. Furthermore, the simulated phonon frequencies are positive, i.e., the phase is dynamically stable, see $\mathrm{S} 7$.

Using the same non-annealed $\mathrm{Au} / \mathrm{Ti}_{3} \mathrm{SiC}_{2}$ films on $\mathrm{SiC}$, we deposited $\sim 700 \mathrm{~nm}$ of $\mathrm{Ir}$ on $\mathrm{Au}$, as illustrated in Figure 2(a). Ir deposition was made thick enough to isolate the sample from the ambient since $\mathrm{Au}$ (unlike Ir) is prone to recrystallization, forming grain boundaries, which can facilitate interdiffusion of gas species. Annealing at $600{ }^{\circ} \mathrm{C}$ for $12 \mathrm{~h}$ and in $\mathrm{N}_{2}$ atmosphere resulted in the A-layers becoming filled with double layers of $\mathrm{Au}$, as can be seen in Figure 
2(b), with a resultant $31 \%$ increase of the $c$ lattice parameter. This is a remarkable extension of the results of single-layer replacement for $\mathrm{Au} / \mathrm{Ti}_{3} \mathrm{SiC}_{2} / \mathrm{SiC}$ samples (Fig. 1(a)). Figure 2(c) shows a STEM/EDX image that reveals locations with different number of $\mathrm{Au}$ layers including the transition between regular two-atomic-layer $\mathrm{Au}$ (top part) and forking between two and three atomic Au layers (mid-section) as well as double-to-triple-layer Au (lower part), resulting in continued swelling in the $c$ direction. Such features can be a result of stacking faults in the original $\mathrm{Ti}_{3} \mathrm{SiC}_{2}$ host (See S.11).

Figure 2(d) shows the STEM image of this phase along the [11 $\overline{2} 0]$ direction. The $\mathrm{Ti}_{3} \mathrm{C}_{2}$ sheets are located in a zig-zag pattern along the $c$ axis, and notably not mirrored with respect to the A-layers as is the case in $\mathrm{Ti}_{3} \mathrm{AuC}_{2}$ and $\mathrm{M}_{3} \mathrm{AX} \mathrm{X}_{2}$ phases. Each two-atom-thick A-layer is composed of two mono-layers of $\mathrm{Au}$ with different in-plane positions. This is a different crystal structure from the only known $\mathrm{M}_{n+1} \mathrm{~A}_{2} \mathrm{X}_{\mathrm{n}}$ phase to-date $\left(\mathrm{Mo}_{2} \mathrm{Ga}_{2} \mathrm{C}\right)$ in which the two monolayers of $\mathrm{Ga}$ forming each A-layer are located directly on top of each other ${ }^{15,16}$. Moreover, the A-layers in $\mathrm{Ti}_{3} \mathrm{Au}_{2} \mathrm{C}_{2}$ are located in a zigzig-zagzag pattern along the $c$ axis, which is also visible in Figure 2(b) in a wider view. Figure 2(e) is a STEM image along the

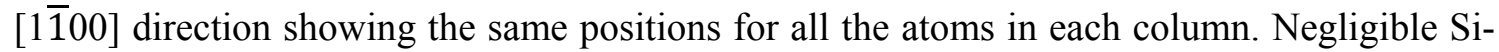
content within the Au-containing regions was determined using EDX. Based on the abovementioned characteristics, we assumed a unit cell within the P-3m1 space group, as illustrated in Figure 2(f). Figure 2(g) shows X-ray diffractograms of the sample in Figure 2(a) before and after the annealing procedure showing the $c$ lattice parameter of $\mathrm{Ti}_{3} \mathrm{Au}_{2} \mathrm{C}_{2}$ to be $23.14 \times 2=$ $46.28 \AA$ (31\% lattice swelling). Ab-initio simulations based on the structure in Figure 2(f) show negative formation enthalpy for this phase (see S3 and S6) as well as dynamic stability (see section S7), thus supporting the determined crystal structure.

Both $\mathrm{Ti}_{3} \mathrm{AuC}_{2}$ and $\mathrm{Ti}_{3} \mathrm{Au}_{2} \mathrm{C}_{2}$ phases showed ohmic behavior on $\mathrm{SiC}$, as characterized by current/voltage $(\mathrm{I} / \mathrm{V})$ measurements ${ }^{14}$ on two separated contact areas $(\approx 3 \mathrm{~mm} \times 8 \mathrm{~mm})$ using two removable probes. In order to investigate the functionality of these structures as hightemperature ohmic contacts, we investigated aging at $600{ }^{\circ} \mathrm{C}$. The $\mathrm{Au} / \mathrm{Ti}_{3} \mathrm{AuC}_{2} / \mathrm{SiC}$ sample remained intact in nitrogen atmosphere for $100 \mathrm{~h}$. However, when annealed in air, this sample completely transformed into $\mathrm{Ti}_{3} \mathrm{Au}_{2} \mathrm{C}_{2}$ within the first $20 \mathrm{~h}$, as confirmed by XRD. After $60 \mathrm{~h}$, the diffraction peaks disappeared due to oxidation into X-ray amorphous phases. We aged the Ir-capped sample depicted in Figure 2(a) for $1000 \mathrm{~h}$ in air. Figure 3 (a) is a low resolution STEM image of the sample after the 1000-h experiment. As can be seen, the Au layer has diffused through Ir forming a $\approx 200 \mathrm{~nm}$ thick layer. Figure 3 (b) is a STEM image of the initial $\mathrm{Ti}_{3} \mathrm{SiC}_{2}$ site after the 1000-h anneal. This site (see above) had completely transformed into $\mathrm{Ti}_{3} \mathrm{Au}_{2} \mathrm{C}_{2}$ after $12 \mathrm{~h}$ of annealing. However, Figure 3 (b) shows that the A layers are filled with monolayers of a heavy metal, instead of double layers. The corresponding EDX in Figure 3 (c) shows them to be composed of Ir with negligible Au content, thus resulting in yet another phase: $\mathrm{Ti}_{3} \mathrm{IrC}_{2}$. Based on STEM results, the structure of $\mathrm{Ti}_{3} \mathrm{IrC}_{2}$ is identical to the regular $\mathrm{M}_{3} \mathrm{AC}_{2}$ structure. DFT results (see S5), further shows that structure has positive formation enthalpy with respect to the most competing phases and exhibits positive phonon frequencies. These findings suggest that $\mathrm{Ti}_{3} \mathrm{IrC}_{2}$ is a metastable $\mathrm{M}_{\mathrm{n}+1} \mathrm{AX}_{\mathrm{n}}$ phase. This is further supported by our attempt to synthesize $\mathrm{Ti}_{3} \mathrm{IrC}_{2}$ through a direct intercalation of Ir into $\mathrm{Ti}_{3} \mathrm{SiC}_{2}$, where a 200 -nm-thick Ir layer was deposited directly on $\mathrm{Ti}_{3} \mathrm{SiC}_{2}$ film grown on $\mathrm{SiC}$, whereafter the sample was annealed for $100 \mathrm{~h}$ at $600{ }^{\circ} \mathrm{C}$. In that case, the annealing process destroyed both the ohmicity and the layered structure of $\mathrm{Ti}_{3} \mathrm{SiC}_{2}$ forming nanocrystalline Tiand Ir-containing intermetallic phases. Electron energy loss spectroscopy of the Au and Ir 
showed no indication of any difference in bonding when compared to those of pure elemental cases (see S.12). These findings indicate a zero (or near-zero) valence state for the noble metals whose bonding state are seemingly of covalent/metallic nature. Note that this should not be confused with the intercalation of zerovalent atoms in van der Waals solids. ${ }^{17-19}$

The ohmicity of the contact remained intact by transformation from $\mathrm{Ti}_{3} \mathrm{Au}_{2} \mathrm{C}_{2}$ to $\mathrm{Ti}_{3} \mathrm{IrC}_{2}$ during the $1000 \mathrm{~h}$ experiment. However, migration of the Au layer towards the surface potentially leaves voids affecting the structural stability ${ }^{13}$ (see S.9). To overcome this, we used $\mathrm{IrO}_{\mathrm{x}}{ }^{20}$ films instead of $\mathrm{Ir}$ (for a high electrical conductivity phase that eliminates surface oxidation as a cause of failure) on Au-covered $\mathrm{Ti}_{3} \mathrm{SiC}_{2}$, see Figure 4 (a). We annealed the sample for $1000 \mathrm{~h}$ in ambient air. The annealing resulted in insertion of single-layer $\mathrm{Au}$ in the $\mathrm{Ti}_{3} \mathrm{SiC}_{2}$ forming $\mathrm{Ti}_{3} \mathrm{AuC}_{2}$. Figure 4 (b) shows an STEM image of such a sample after annealing for $1000 \mathrm{~h}$ at $600{ }^{\circ} \mathrm{C}$ and in ambient air. As can be seen, the $\mathrm{Ti}_{3} \mathrm{AuC}_{2} / \mathrm{Au}$ stack has remained intact, showing that this design is stable. Figure 4 (c) is the I/V curve after the 1000 $\mathrm{h}$ annealing experiment, showing a retained linear characteristic of ohmic contacts. A contact with the use of $\mathrm{IrO}_{\mathrm{x}}$ directly on $\mathrm{Ti}_{3} \mathrm{SiC}_{2} / \mathrm{SiC}$ as an oxygen barrier lasts for less than $100 \mathrm{~h}$ at $600{ }^{\circ} \mathrm{C}$ air as observed by I/V and XRD (see S.10).

In order to explain the massive replacement of $\mathrm{Si}$ with $\mathrm{Au}$ in $\mathrm{Ti}_{3} \mathrm{SiC}_{2}$, we recall that $\mathrm{Au}$ induces instability in the bonding character of the $\mathrm{Si}$ adjacent to the $\mathrm{Au}$ in $\mathrm{Au}-\mathrm{Si}$ diffusion couples by screening of the Coulomb interaction by its free electrons. ${ }^{21}$ In bulk, the $\mathrm{Au}-\mathrm{Si}$ system forms a deep eutectic at $363{ }^{\circ} \mathrm{C}$, well below our annealing temperature. A liquid phase is present throughout the entire phase diagram with no solid silicide phases. Au and Si have no mutual solubility in the solid state while $\mathrm{Si}$ surface-segregation in $\mathrm{Au}-\mathrm{Si}$ alloys, or in $\mathrm{Au}-$ covered $\mathrm{Si}$ substrates, is also known. ${ }^{22,23} \mathrm{Si}$ atoms are loosely bonded to $\mathrm{Ti}_{3} \mathrm{SiC}_{2}$ as a general trend in $\mathrm{M}_{\mathrm{n}+1} \mathrm{AX}_{\mathrm{n}}$ phases. At $600{ }^{\circ} \mathrm{C}$ and in the presence of $\mathrm{Au}$ reservoir surrounding the $\mathrm{Ti}_{3} \mathrm{SiC}_{2}$ grains as the primarily most possible diffusion path, the loosely bonded $\mathrm{Si}$ atoms find a lower chemical potential diffusing in $\mathrm{Au}$. The presence of stacking faults in $\mathrm{Ti}_{3} \mathrm{SiC}_{2}$ can likely accelerate the diffusion. This leaves the A-layers vacant which in turn are back-filled with $\mathrm{Au}$ atoms, while appreciating volume constraints for diffusion on the A-layers imposed by the present $\mathrm{Ti}_{3} \mathrm{SiC}_{2}$ films. The above-mentioned factors are also consistent with the fact that $\mathrm{Ti}_{3} \mathrm{IrC}_{2}$ could not be formed here by annealing $\mathrm{Ir} / \mathrm{Ti}_{3} \mathrm{SiC}_{2} / \mathrm{SiC}$ samples at $600{ }^{\circ} \mathrm{C}$. At this temperature, the entire Ir-Si phase diagram consists of several solid silicide phases which formation seemingly hinders the out-diffusion of $\mathrm{Si}^{24}$ For the case of successful Ir indiffusion in $\mathrm{Ti}_{3} \mathrm{Au}_{2} \mathrm{C}_{2}, \mathrm{Au}$ and $\mathrm{Ir}$ exhibit very little mutual solubility while forming no compounds possibly able of blocking the diffusion process. ${ }^{25}$ Moreover, surface segregation of $\mathrm{Au}$ in $\mathrm{Au}$-Ir alloys is also expected. ${ }^{26}$ Based on these while taking into account the high diffusivity of $\mathrm{Au}$, the synthesis of $\mathrm{Ti}_{3} \mathrm{IrC}_{2}$ can be explained.

The remarkable stability of the $\mathrm{Ti}_{3} \mathrm{AuC}_{2}$ ohmic contact to $\mathrm{SiC}$ stands out. $\mathrm{SiC}$ is a preferred choice for high temperature electronics based on its highly stable electronic and structural properties at elevated temperature ${ }^{27,28}$. Yet, the degradation of the metallic ohmic contacts needs to be overcome ${ }^{13}$ in order for it to find its path into high-temperature industrial applications, e.g., in situ chemical gas sensors for exhaust monitoring of vehicles ${ }^{29}$. Other reports at similar conditions to our aging experiments show complete degradation of the contact at considerably less thermal loading and period ${ }^{30,31}$. 
220 In conclusion, we have discovered the layered $\mathrm{Ti}_{3} \mathrm{AuC}_{2}, \mathrm{Ti}_{3} \mathrm{Au}_{2} \mathrm{C}_{2}$, and $\mathrm{Ti}_{3} \mathrm{IrC}_{2}$ phases by 221 ordered noble-metal exchange of A-layers in nanolaminated transition metal carbides, $222 \mathrm{M}_{\mathrm{n}+1} \mathrm{AX}_{\mathrm{n}}$ phases. The formation mechanism and the resulting phases are structurally and 223 reaction-wise different to intercalation of other species into $\mathrm{Si}$ - or Al-depleted two224 dimensional MXene phases ${ }^{11,12}$, which host the intercalation species inside the laminar voids 225 in between their layers. Here, the reaction takes place through an ordered exchange on 226 specific crystal planes, with $\mathrm{Au}$ planes substituting for $\mathrm{Si}$ and $\mathrm{Ir}$ for double-Au planes, 227 respectively. These results constitute a starting point for exploration of what is likely to be a 228 large family of noble-metal-containing transition-metal carbides/nitrides. Also, they offer 229 prospects and means for property tailoring in nanolaminated functional ceramics, as 230 demonstrated here for high-temperature ohmicity with corresponding implications for 231 enhanced electrical or magnetic properties. 


\section{METHODS}

The depositions were performed using $4^{\circ}$ off-axis n-type 4H-SiC substrates with $\sim 10{ }^{18} \mathrm{~cm}^{-3}$ of carrier concentration and $10 \times 10 \mathrm{~mm}$ in size. The growth and characterization method for $\mathrm{Ti}_{3} \mathrm{SiC}_{2}$ ohmic contacts was described elsewhere ${ }^{14}$. For the synthesis of $\mathrm{Au}$ and Ir layers, the samples were transferred (ex situ) into a second ultra-high vacuum stainless steel sputtering chamber, equipped with 4 magnetrons placed $20 \mathrm{~cm}$ above the substrate surface, each at $20^{\circ}$ off the substrate normal, with the base pressure lower than $10^{-8} \mathrm{~Pa}$ obtained by a $550 \mathrm{l} / \mathrm{s}$ turbo molecular pump backed by a rotary vane pump. Prior to the depositions, the surface of the $\mathrm{Ti}_{3} \mathrm{SiC}_{2}$ Ohmic contacts where cleaned by a 5 -second dip in buffered $\mathrm{HF}\left(\mathrm{NH}_{3} \mathrm{~F}\right.$ (25 gr) + $\left.\mathrm{H}_{2} \mathrm{O}(50 \mathrm{ml})+\mathrm{HF}(10 \mathrm{ml})\right)$ to remove any surface oxide followed by a thorough rinse in distilled water, blow-dried in $\mathrm{N}_{2}$ and inserted into the load-lock of the deposition system. All sputtering targets were 2 inches in diameter with the purity of $99.99 \%$ or higher. Ar was used as the sputtering gas with the constant pressure of 1.8 mtorr. For the growth of $\mathrm{IrO}_{\mathrm{x}}$, (see S8). $25 \%$ of partial pressure of $\mathrm{O}_{2} / \mathrm{Ar}$ was used for sputtering. All the sputter-depositions were in DC mode with the current (mA) and voltages (V) of $[(520),(420)]_{\mathrm{Ir}},[(240),(440)]_{\mathrm{Au}},[(250)$, (570)] ${ }_{\text {IrOx }}$ which yielded the deposition rates of $\mathrm{r}_{\mathrm{Ir}}=350 \AA / \mathrm{s}, \mathrm{r}_{\mathrm{Au}}=260 \AA / \mathrm{s}$, and $\mathrm{r}_{\mathrm{IrOx}}=350$ $\AA /$ s obtained using scanning electron microscopy (SEM) for cross-sectional samples. All the depositions were performed with floating substrate bias and at room temperature. The reason for the low temperature was to obtain a fine-grained microstructure and avoid columnar growth and the consequent column boundaries which can act as oxygen diffusion paths. X-ray diffraction (XRD) was performed using a Philips PW 1820 instrument $(\mathrm{Cu}(\mathrm{K} \alpha), \theta-2 \theta$ scan, aligned with the substrate (0001) peak). SEM was performed in a LEO 1550 for film thickness measurement via cross-sectional samples and surface imaging. Transmission electron microscopy (TEM) was performed in the Linköping monochromated doublespherical-aberration-corrected FEI Titan3 60-300 operated at $300 \mathrm{kV}$, equipped with the SuperX EDX system. Cross-sectional samples were first mechanically polished to a thickness of about $50 \mu \mathrm{m}$, followed by ion-beam milling with $\mathrm{Ar}^{+}$in a Gatan precision ion polishing system (PIPS) at $5 \mathrm{keV}$ with a final polishing step at $1 \mathrm{keV}$ of ion energies. The annealing procedure was performed in a cylindrical ceramic oven, exposed to ambient air, in which the sample is placed at its center. The temperature was controlled simultaneously during the whole experiments using a thermocouple at the sample position. The temperature of the oven was raised with the ramp of $17.6^{\circ} \mathrm{C} / \mathrm{min}$ to the annealing temperature of $650{ }^{\circ} \mathrm{C}$.

\section{ACKNOWLEDGMENTS}

We acknowledge Dr. Henrik Pedersen for useful discussions about the results. We acknowledge the support from the VINN Excellence Center in research and innovation on Functional Nanoscale Materials (FunMat) by the Swedish Governmental Agency for Innovation Systems (VINNOVA) and the Swedish Government Strategic Research Areas in Materials Science on Functional Materials at Linköping University (Faculty Grant SFO-MatLiU No. 2009 00971). P.E, J.L., M.D., and J.R. also acknowledge support from the Swedish Foundation for Strategic Research through the Future Research Leaders 5 Program and the Synergy Grant FUNCASE, Functional Carbides and Advanced Surface Engineering. I.A.A. is grateful to support provided by the e-Science Research Centre (SeRC). P. E. also acknowledges support from the European Research Council under the European Community's Seventh Framework Programme (FP/2007-2013) / ERC grant agreement no 
335383. L.H. acknowledges the Knut and Alice Wallenberg Foundation for a Scholar Grant and support to the Linköping Ultra Electron Microscopy Laboratory. The calculations were performed on resources provided by the Swedish National Infrastructure for Computing (SNIC) at National Supercomputer Centre (NSC) and PDC.

\section{ADDITIONAL INFORMATION}

Supplementary information is available in the online version of the paper. Correspondence and requests for materials should be addressed to M. A., A.L.S, and P.E.

\section{DATA AVAILABILITY STATEMENT}

Essential all data generated or analyzed during this study are included in this published article (and its supplementary information files). The datasets (computational data and source data for graphs) generated during and/or analyzed during the current study are available in the Zenodo repository at https://doi.org/10.5281/zenodo.376969.

\section{COMPETING FINANCIAL INTERESTS}

The authors declare no competing financial interests.

\section{AUTHOR CONTRIBUTIONS}

H.F, M. A., A. L.-S., and P. E. conceived and initiated the work. H. F. conducted and analyzed the growth, annealing, XRD, and SEM. M.D. performed the $a b$ initio studies with input from S. I. S., I. A.A., J. R., H.F., and P.E.

J.L. conducted the STEM and EDX and analyzed the results with contributions from H.F., L.H and P.E.

J. P. designed, executed, and interpreted the in-situ annealing in TEM, and recorded the movie.

H.F., M.D., and P.E. wrote the manuscript with contributions from the other coauthors. All coauthors read and commented on successive drafts of the manuscript.

M. A., A. L.-S., and P.E. supervised the work. 


\section{REFERENCES}

1. Barsoum, M. W. \& Radovic, M. Elastic and Mechanical Properties of the MAX Phases. Annu. Rev. Mater. Res. 41, 195-227 (2011).

2. $\quad$ Eklund, P., Beckers, M., Jansson, U., Högberg, H. \& Hultman, L. The $\mathrm{M}_{\mathrm{n}+1} \mathrm{AX}_{\mathrm{n}}$ phases: Materials science and thin-film processing. Thin Solid Films 518, 1851-1878 (2010).

3. Naguib, M., Mochalin, V. N., Barsoum, M. W. \& Gogotsi, Y. $25^{\text {th }}$ anniversary article: MXenes: a new family of two-dimensional materials. Adv. Mater. 26, 992-1005 (2014).

4. Naguib, M. et al. Two-dimensional nanocrystals produced by exfoliation of $\mathrm{Ti}_{3} \mathrm{AlC}_{2}$. Adv . Mater. 23, 4248-53 (2011).

5. Halim, J. et al. Synthesis and Characterization of 2D Molybdenum Carbide (MXene). Adv. Funct. Mater. 26, 3118-3127 (2016).

6. Dillon, A. D. et al. Highly Conductive Optical Quality Solution-Processed Films of 2D Titanium Carbide. Adv. Funct. Mater. 26, 3118-3127 (2016).

7. Urbankowski, P. et al. Synthesis of two-dimensional titanium nitride Ti4N3 (MXene). Nanoscale 8, 11385-11391 (2016).

8. Zhou, J. et al. A Two-Dimensional Zirconium Carbide by Selective Etching of $\mathrm{Al}_{3} \mathrm{C}_{3}$ from Nanolaminated $\mathrm{Zr}_{3} \mathrm{Al}_{3} \mathrm{C}_{5}$. Angew. Chem. Int. Ed. 55, 5008-5013 (2016).

9. Ghidiu, M., Lukatskaya, M. R., Zhao, M.-Q., Gogotsi, Y. \& Barsoum, M. W. Conductive twodimensional titanium carbide 'clay' with high volumetric capacitance. Nature 516, 78-81 (2014).

10. Ling, Z. et al. Flexible and conductive MXene films and nanocomposites with high capacitance. Proc. Natl. Acad. Sci. U. S. A. 111, 16676-81 (2014).

11. Lukatskaya, M. R. et al. Cation intercalation and high volumetric capacitance of twodimensional titanium carbide. Science 341, 1502-5 (2013).

12. Mashtalir, O. et al. Intercalation and delamination of layered carbides and carbonitrides. Nat. Commun. 4, 1716 (2013).

13. Wang, Z., Liu, W. \& Wang, C. Recent Progress in Ohmic Contacts to Silicon Carbide for High-Temperature Applications. J. Electron. Mater. 45, 267-284 (2016)

14. Fashandi, H. et al. Single-step synthesis process of $\mathrm{Ti}_{3} \mathrm{SiC}_{2}$ ohmic contacts on $4 \mathrm{H}-\mathrm{SiC}$ by sputter-deposition of Ti. Scr. Mater. 99, 53-56 (2015).

15. Lai, C.-C. et al. Structural and chemical determination of the new nanolaminated carbide $\mathrm{Mo}_{2} \mathrm{Ga}_{2} \mathrm{C}$ from first principles and materials analysis. Acta Mater. 99, 157-164 (2015).

16. Hu, C. et al. $\mathrm{Mo}_{2} \mathrm{Ga}_{2} \mathrm{C}$ : a new ternary nanolaminated carbide. Chem. Commun. (Camb). 51, 6560-3 (2015).

17. Koski, K. J. et al. High-density chemical intercalation of zero-valent copper into $\mathrm{Bi}_{2} \mathrm{Se}_{3}$ nanoribbons. J. Am. Chem. Soc. 134, 7584-7 (2012).

18. Yao, J. et al. Optical transmission enhancement through chemically tuned two-dimensional bismuth chalcogenide nanoplates. Nat. Commun. 5, 5670 (2014).

19. Motter, J. P., Koski, K. J. \& Cui, Y. General Strategy for Zero-Valent Intercalation into TwoDimensional Layered Nanomaterials. Chem. Mater. 26, 2313-2317 (2014).

20. Trupina, L. et al. Iridium layer as oxygen barrier and growth substrate for oriented PZT thin films. 9, 1508-1510 (2007).

21. Tu, K. N. Selective growth of metal-rich silicide of near-noble metals. Appl. Phys. Lett. 27, 221 (1975).

22. Hiraki, A. Formation of silicon oxide over gold layers on silicon substrates. J. Appl. Phys. 43, 3643 (1972). 
23. Lee, S., Stephens, J. A. \& Hwang, G. S. On the Nature and Origin of Si Surface Segregation in Amorphous AuSi Alloys. 3037-3041 (2010).

24. Hg-Ho - La-Zr. Madelung, O., Ed.; Landolt-Börnstein - Group IV Physical Chemistry; Springer-Verlag: Berlin/Heidelberg, 1997; Vol. G.

25. $\quad A c-A u-A u-Z r$. Madelung, O., Ed.; Landolt-Börnstein - Group IV Physical Chemistry; Springer-Verlag: Berlin/Heidelberg, 1991; Vol. A.

26. Ruban, A. V, Skriver, H. L. \& No, J. K. Surface segregation energies in transition-metal alloys. 59, 990-1000 (1999).

27. Hedayati, R., Lanni, L., Rusu, A. \& Zetterling, C.-M. Wide Temperature Range Integrated Bandgap Voltage References in 4H-SiC. IEEE Electron Device Lett. 37, 146-149 (2016).

28. Wijesundara, M. \& Azevedo, R. Silicon Carbide Microsystems for Harsh Environments. (Springer New York, 2011).

29. Andersson, M., Pearce, R. \& Lloyd Spetz, A. New generation SiC based field effect transistor gas sensors. Sensors Actuators B Chem. 179, 95-106 (2013).

30. Daves, W., Krauss, A., Haublein, V., Bauer, A. J. \& Frey, L. Structural and Reliability Analysis of Ohmic Contacts to $\mathrm{SiC}$ with a Stable Protective Coating for Harsh Environment Applications. ECS J. Solid State Sci. Technol. 1, P23-P29 (2012).

31. Virshup, A. et al. Investigation of Thermal Stability and Degradation Mechanisms in Ni-Based Ohmic Contacts to n-Type SiC for High-Temperature Gas Sensors. J. Electron. Mater. 38, 569-573 (2009). 

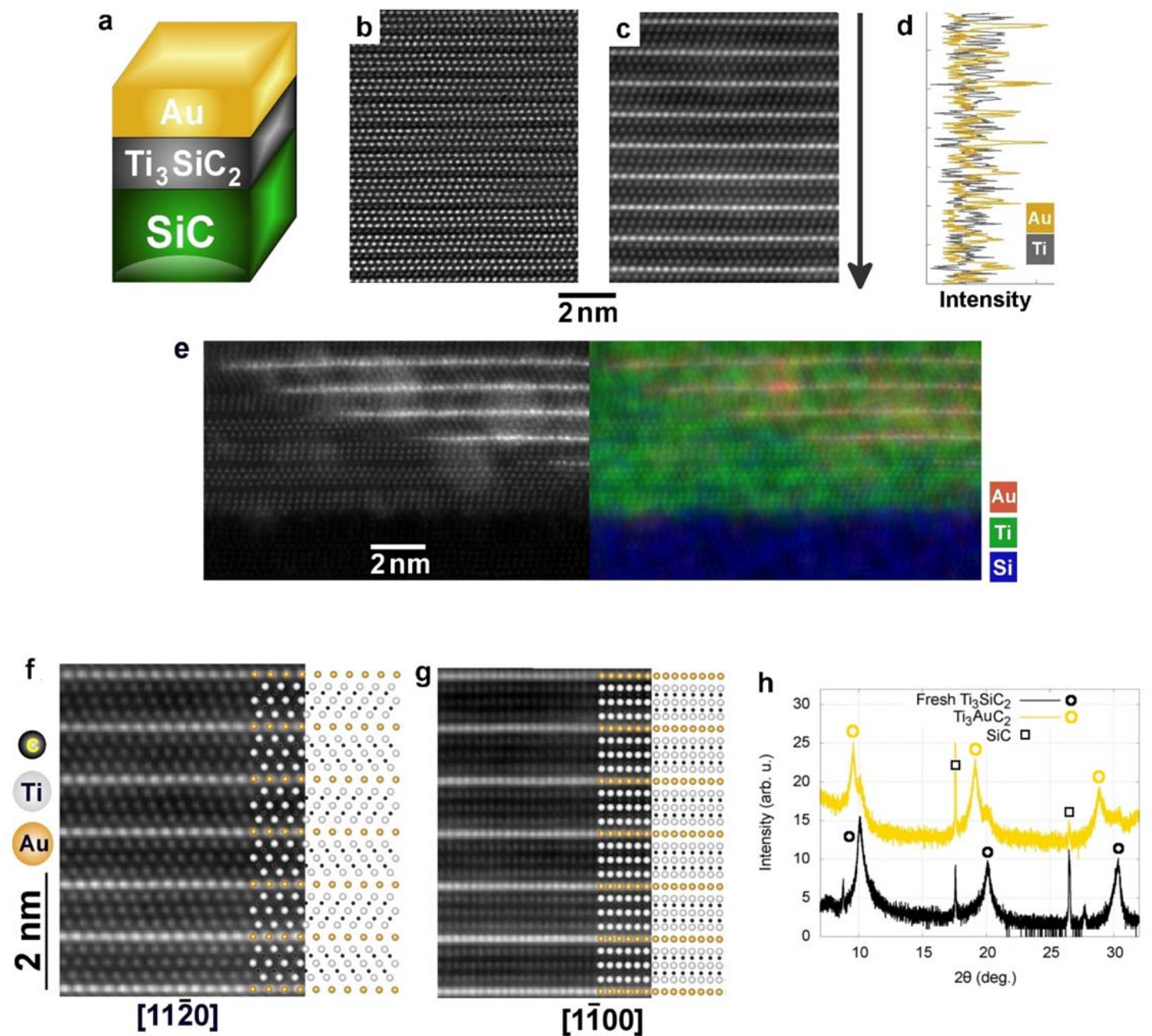

Figure 1. Transformation from $\mathbf{T i}_{3} \mathrm{SiC}_{2}$ to $\mathbf{T i}_{3} \mathbf{A u C}_{2}$. (a) Schematic illustration of the goldcovered $\mathrm{Ti}_{3} \mathrm{SiC}_{2}$ layer on $\mathrm{SiC}$ prior to the reaction at $670{ }^{\circ} \mathrm{C}$. (b) HR-STEM image of the $\mathrm{Ti}_{3} \mathrm{SiC}_{2}$ site of the sample illustrated in (a) prior to the annealing. (c) HR-STEM of $\mathrm{Ti}_{3} \mathrm{AuC}_{2}$ phase formed between the $\mathrm{SiC}$ and the Au during the annealing. (d) EDX line-scan along the arrow depicted in (c) mapping Ti-K $\alpha$ and Au-M $\alpha$ signals. (e) HR-STEM and the corresponding EDX map of the annealed sample showing Au diffusing in between the $\mathrm{Ti}_{3} \mathrm{C}_{2}$ layers. (f) and (g) Atomic positions of $\mathrm{Ti}_{3} \mathrm{AuC}_{2}$ from different orientations based on HRSTEM results. (h) $0001\left(\mathrm{l}=2,4\right.$, and 6) peaks of the XRD patterns of $\mathrm{Ti}_{3} \mathrm{SiC}_{2}$ and $\mathrm{Ti}_{3} \mathrm{AuC}_{2}$ before and after the annealing, respectively. 

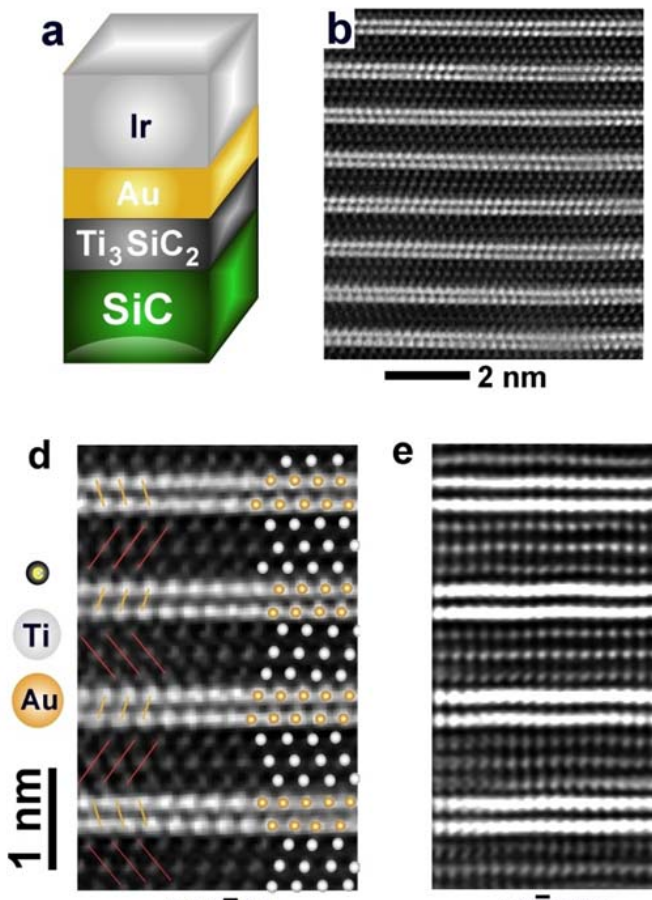

[112̄0] e

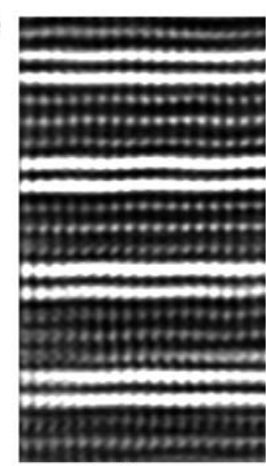

[1̄̄00]

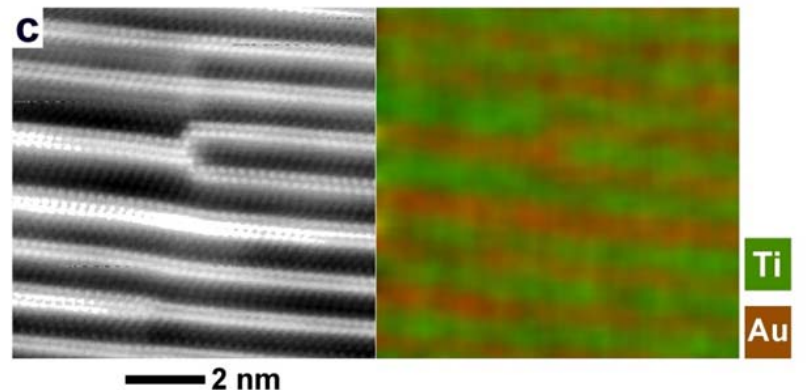

f

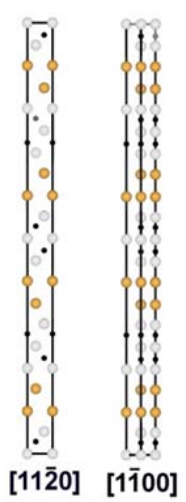

g

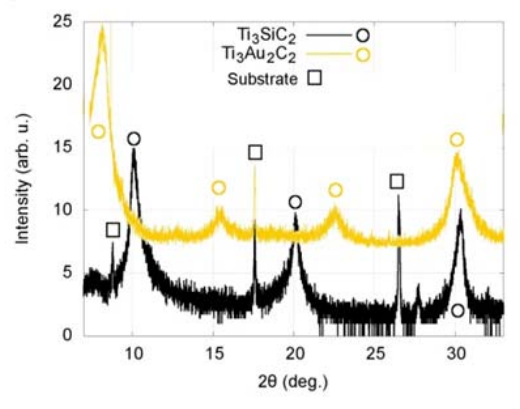

Figure 2. Transformation from $\mathbf{T i}_{3} \mathrm{SiC}_{2}$ to $\mathbf{T i}_{3} \mathbf{A u}_{2} \mathbf{C}_{2}$. (a) Schematic illustration of the iridium- and gold-covered $\mathrm{Ti}_{3} \mathrm{SiC}_{2}$ layer on $\mathrm{SiC}$ prior to the reaction at $600{ }^{\circ} \mathrm{C}$. (b) $\mathrm{Ti}_{3} \mathrm{Au}_{2} \mathrm{C}_{2}$ formed between the $\mathrm{SiC}$ and the Au during the annealing. (c) HR-STEM and corresponding EDX of Ti-K $\alpha$ and Au-M $\alpha$ signals showing stacking faults in $\mathrm{Ti}_{3} \mathrm{Au}_{2} \mathrm{C}_{2}$. (d) Atomic positions and stacking orders of $\mathrm{Ti}_{3} \mathrm{Au}_{2} \mathrm{C}_{2}$ based on HR-STEM along the [11 $\left.\overline{2} 0\right]$ direction. (e) HRSTEM of atomic positions along [1 $1 \overline{1} 00]$. (f) Unit cell for $\mathrm{Ti}_{3} \mathrm{Au}_{2} \mathrm{C}_{2}$ neglecting the disorders along the Au planes. (g) (0001) peaks in the X-ray diffractograms of $\mathrm{Ti}_{3} \mathrm{SiC}_{2}$ and $\mathrm{Ti}_{3} \mathrm{Au}_{2} \mathrm{C}_{2}$. 
a

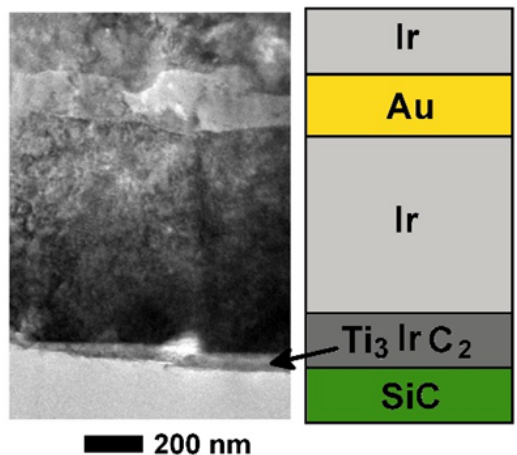

b

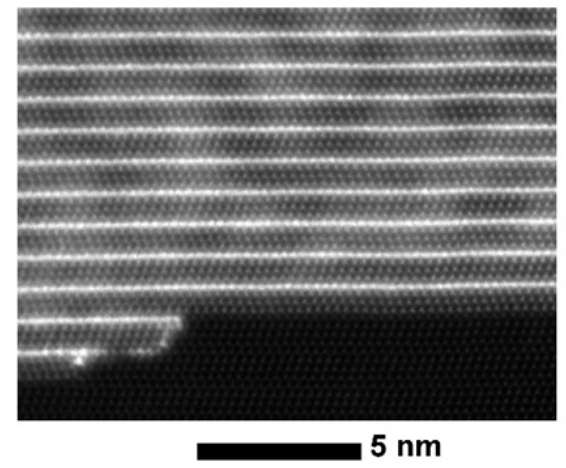

C

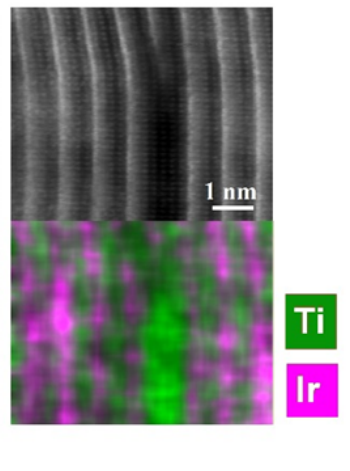

399

400

401

402

403

404

a

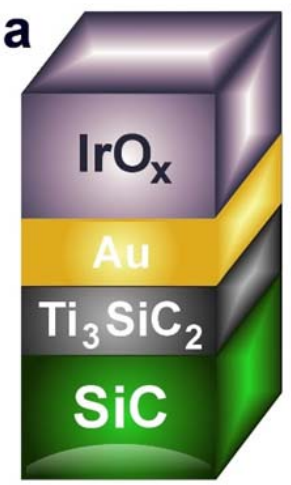

Figure 3. Transformation from $\mathrm{Ti}_{3} \mathrm{Au}_{2} \mathrm{C}_{2}$ to $\mathrm{Ti}_{3} \mathrm{IrC}_{2}$ by metal exchange. (a) Lowresolution STEM of $\mathrm{Ir} / \mathrm{Au} / \mathrm{Ti}_{3} \mathrm{Au}_{2} \mathrm{C}_{2} / \mathrm{SiC}$ sample annealed for $500 \mathrm{~h}$ in $600{ }^{\circ} \mathrm{C}$ along with the schematic illustration of the layers stacking change due to the annealing. (b) High resolution STEM of $\mathrm{Ti}_{3} \mathrm{IrC}_{2}$. (c) Energy dispersive X-ray spectroscopy of Ti and Ir signals of $\mathrm{Ti}_{3} \mathrm{IrC}_{2}$.

405

Figure 4. Stability of $\mathrm{Ti}_{3} \mathrm{AuC}_{2}$ based ohmic contact at $600{ }^{\circ} \mathrm{C}$. (a) Schematic illustration of

b

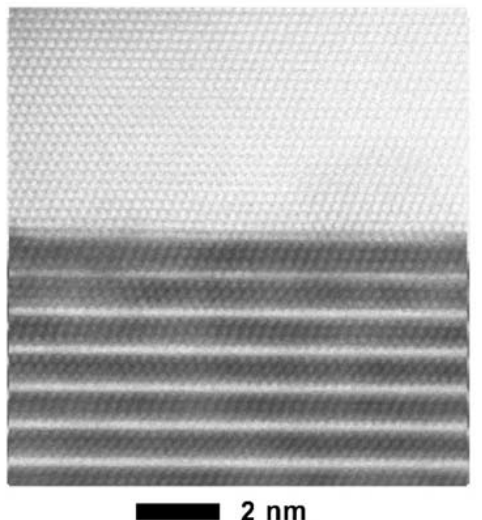

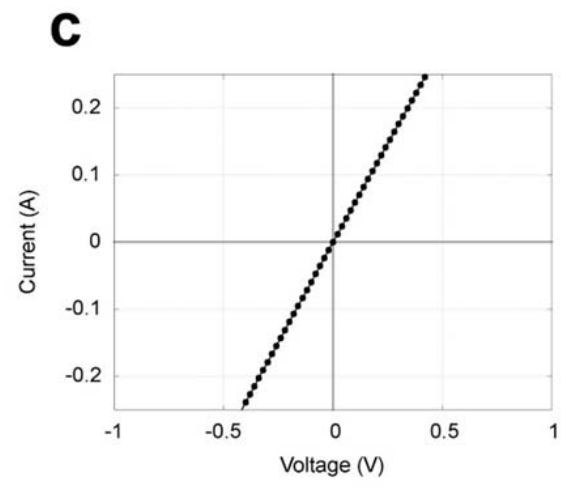

C

the as-deposited ohmic contact structure, (b) and (c) the interface between the Au and the $\mathrm{Ti}_{3} \mathrm{AuC}_{2}$ sites and the current/voltage curve after $1000 \mathrm{~h}$ of aging at $600{ }^{\circ} \mathrm{C}$, respectively. 







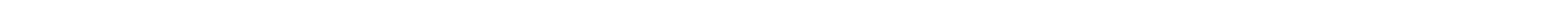




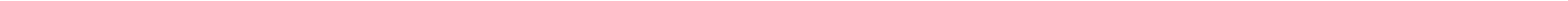


Supplementary information for

Synthesis of $\mathrm{Ti}_{3} \mathrm{AuC}_{2}, \mathrm{Ti}_{3} \mathrm{Au}_{2} \mathrm{C}_{2}$ and $\mathrm{Ti}_{3} \mathrm{IrC}_{2}$ by noble-metal substitution reaction in $\mathrm{Ti}_{3} \mathrm{SiC}_{2}$ for high-temperature-stable ohmic contacts to $\mathrm{SiC}$

Hossein Fashandi, Martin Dahlqvist, Jun Lu, Justinas Palisaitis, Sergei I. Simak, Igor A. Abrikosov, Johanna Rosen, Lars Hultman, Mike Andersson*, Anita Lloyd Spetz*, and Per Eklund*

Department of Physics, Chemistry, and Biology (IFM), Linköping University, SE-581 83 Linköping, Sweden

KEYWORDS: Layered phases, noble metals, MAX phase ohmic contacts, oxidation resistance 


\section{Section S1. Si out-diffusion}

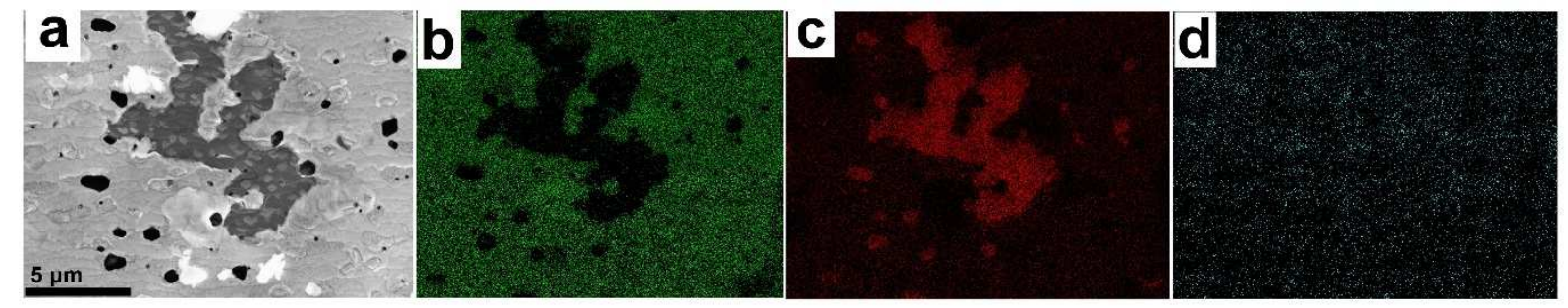

Figure S1. Scanning electron microscopy (SEM) images of the surface of annealed $\mathrm{SiC} / \mathrm{Ti}_{3} \mathrm{SiC}_{2} / \mathrm{Au}$. (a) SEM image showing different islands formed on the surface after annealing, (b) Energy dispersive X-ray spectroscopy of Au M $\alpha$ signal showing the dark islands to be deficient in $\mathrm{Au}$, (c) that of $\mathrm{Si} \mathrm{K \alpha}$ showing the dark islands to be Si-rich, (d) that of $\mathrm{Ti} \mathrm{K} \alpha$ which rules out any of the dark regions to be exposed $\mathrm{Ti}_{3} \mathrm{SiC}_{2}$ or $\mathrm{Ti}_{3} \mathrm{AuC}_{2}$. 


\section{Section S2. Computational details}

First-principles calculations were performed by means of density functional theory (DFT) and the projector augmented wave method ${ }^{1,2}$ as implemented within the Vienna ab-initio simulation package $(\mathrm{VASP})^{3-5}$. We adopted the generalized gradient approximation (GGA) as parameterized by Perdew-Burke-Ernzerhof $(\mathrm{PBE})^{6}$ for treating electron exchange and correlation effects. Calculations including spin-orbit coupling have been performed in the mode implemented in VASP by Hobbs et al. ${ }^{7}$ and Marsman and Hafner ${ }^{8}$ and performed in two steps. First a scalar-relativistic calculation has been performed to obtain the correct geometry. In those cases where the ternary phase contains Au or Ir we used the ground state resulting from the scalar-relativistic calculations to initialize the calculations including spin-orbit coupling. A plane-wave energy cut-off of $500 \mathrm{eV}$ was used and for sampling of the Brillouin zone we used the Monkhorst-Pack scheme ${ }^{9}$. For each considered phase, the geometric and electronic degrees of freedom were relaxed simultaneously until the change in total energy between successive iteration steps was smaller than $10^{-6} \mathrm{eV}$. Calculations were performed at zero temperature and pressure and all structures were fully relaxed.

Thermodynamic stability at $0 \mathrm{~K}$ is expressed as formation enthalpy $\Delta \mathrm{H}_{\mathrm{cp}}$ and calculated by comparing its total energy with respect to competing phases. Included competing phases are based on experimental phase diagrams and what is present in similar systems (see section S6). In order to find which combination of competing phases having the lowest energy we apply a linear optimization procedure based on the simplex method. Further details are given in Refs. ${ }^{10,11}$ To determine the dynamical stability of the studied ordered structure, we performed phonon calculations using the small displacement method, supercell sizes of at least $3 \times 3 \times 1$ unit cells, along with the code Phonopy ${ }^{12}$. Density of states (DOS) and chemical bonding were investigated in terms of projected crystal orbital Hamiltonian populations ( $\mathrm{pCOHP}$ ) which were derived using the LOBSTER program ${ }^{9,12,13}$. Using this method the calculated band-structure energy is reconstructed into orbital interactions. Positive pCOHP values indicate an antibonding interaction, and negative pCOHP values indicate a bonding interaction.

\section{Section S3. Ti-Au-C system}


Calculated formation enthalpies $\Delta \mathrm{H}_{\mathrm{cp}}$ along with lattice parameters are shown in Table $\mathrm{S} 1$ for $\mathrm{Ti}_{n+1} \mathrm{AuC}_{n}$, where $n=1,2,3$. For $n=1, \Delta \mathrm{H}_{\text {cp }}$ is positive indicating that the structure is not stable with respect to its competing phases. However, $n=2$ and 3 are found stable as seen by their negative $\Delta \mathrm{H}_{\mathrm{cp}}$. Note that for $\mathrm{Ti}_{3} \mathrm{AuC}_{2}$ this is $-14 \mathrm{meV} /$ atom. From experiment it was also observed that $\mathrm{Au}$ can form a double layer between $\mathrm{Ti}_{n+1} \mathrm{C}_{n}$ sheets when replacing $\mathrm{Si}$. Such double $A$-layer formation has previously been reported for $\mathrm{Mo}_{2} \mathrm{Ga}_{2} \mathrm{C}$ with $\mathrm{Ga}$ atoms stacked on top of each other. For $\mathrm{Ti}_{3} \mathrm{Au}_{2} \mathrm{C}_{2}$, see Fig. S2(a), such stacking gives a positive $\Delta \mathrm{H}_{\mathrm{cp}}$, i.e., it is not stable, and it is not observed in TEM where Au atoms are instead in a close-packed arrangement along the [0001]. Based on this information several different candidate stackings were considered. Fig S2(b to d) displays a subset of those. Structure (b) is found to have the lowest energy and be stable (-23 meV/atom), but it has a zig-zig stacking of the $\mathrm{Ti}_{n+1} \mathrm{C}_{n}$ sheets. This structure is therefore unlikely taken into account the formation of $\mathrm{Ti}_{3} \mathrm{Au}_{2} \mathrm{C}_{2}$ from $\mathrm{Ti}_{3} \mathrm{SiC}_{2}$ where the latter have a zig-zag stacking. From TEM, we observe the zig-zag stacking of $\mathrm{Ti}_{n+1} \mathrm{C}_{n}$ sheets and the zig-zig-zag-zag stacking of the Au double layer along the [0001]. This criterion is fulfilled by the structure seen in Fig S2(c), space group $\mathrm{P} \overline{3} \mathrm{~m} 1$, and it is also stable with $\Delta \mathrm{H}_{\mathrm{cp}}$ $=-21 \mathrm{meV} /$ atom. Further crystallographic information for the $\mathrm{P} \overline{3} \mathrm{~m} 1$ structure is given in Table S2.

Table S1. Considered atomic stackings, calculated formation enthalpy and lattice parameters for $\mathrm{Ti}_{n+1} \mathrm{AuC}_{n}$, where $n=1,2,3$ and $\mathrm{Ti}_{3} \mathrm{Au}_{2} \mathrm{C}_{2}$. The influence of spin-orbit coupling on $\Delta \mathrm{H}_{\mathrm{cp}}$ have been considered for selected phases; the corresponding values are given within parenthesis.

\begin{tabular}{cccccc}
\hline \hline Phase & Space group & $a(\AA)$ & $c(\AA)$ & $\Delta \mathrm{H}_{\mathrm{cp}}(\mathrm{meV} /$ atom) & Competing phases \\
\hline $\mathrm{Ti}_{2} \mathrm{AuC}$ & $\mathrm{P} 6_{3} / \mathrm{mmc}(\# 194)$ & 3.0686 & 13.741 & +13 & $\mathrm{Ti}_{3} \mathrm{AuC}_{2}, \mathrm{TiAu}$ \\
$\mathrm{Ti}_{3} \mathrm{AuC}_{2}$ & $\mathrm{P} 6_{3} / \mathrm{mmc}(\# 194)$ & 3.0852 & 18.633 & $-14(-14)$ & $\mathrm{Ti}_{4} \mathrm{AuC}_{3}, \mathrm{TiAu}$ \\
$\mathrm{Ti}_{4} \mathrm{AuC}_{3}$ & $\mathrm{P}_{3} / \mathrm{mmc}(\# 194)$ & 3.0868 & 23.578 & $-1(-1)$ & $\mathrm{Ti}_{3} \mathrm{AuC}_{2}, \mathrm{TiC}$ \\
\hline $\mathrm{Ti}_{3} \mathrm{Au}_{2} \mathrm{C}_{2}$ & $\mathrm{P} 6_{3} / \mathrm{mmc}(\# 194)$ & 3.0852 & 23.831 & +12 & $\mathrm{TiC}, \mathrm{TiAu}_{2}$ \\
& $\mathrm{P} 3 \mathrm{~m} 1(\# 156)$ & 3.0977 & 34.393 & -23 & $\mathrm{TiC}, \mathrm{TiAu}_{2}$ \\
& $\mathrm{P} \overline{3} \mathrm{~m} 1(\# 164)$ & 3.0972 & 45.876 & $-21(-11)$ & $\mathrm{TiC}, \mathrm{TiAu}_{2}$ \\
& $\mathrm{R} \overline{3} \mathrm{~m}(\# 166)$ & 3.0972 & 68.811 & -21 & $\mathrm{TiC}, \mathrm{TiAu}_{2}$ \\
\hline \hline
\end{tabular}

Table S2. Calculated crystallographic information for $\mathrm{Ti}_{3} \mathrm{Au}_{2} \mathrm{C}_{2}$ with space group $\mathrm{P}-3 \mathrm{~m} 1$ (\#164). Wyckoff positions are given for each unique crystallographic site. Structure illustrated in Fig. S2(c). 


\begin{tabular}{lllrrr}
\hline Element & Wyckoff symbol & Symmetry & $\mathrm{x}$ & $\mathrm{y}$ & $\mathrm{z}$ \\
\hline $\mathrm{Ti}$ & $1 a$ & $\overline{3} \mathrm{~m}$. & 0 & 0 & 0 \\
$\mathrm{Ti}$ & $1 b$ & $3 \mathrm{~m}$. & 0 & 0 & $1 / 2$ \\
$\mathrm{Ti}$ & $2 c$ & $3 \mathrm{~m}$. & 0 & 0 & 0.19845 \\
$\mathrm{Ti}$ & $2 d$ & $3 \mathrm{~m}$. & $1 / 3$ & $2 / 3$ & -0.05163 \\
$\mathrm{Ti}$ & $2 d$ & $3 \mathrm{~m}$. & $1 / 3$ & $2 / 3$ & 0.25003 \\
$\mathrm{Ti}$ & $2 d$ & $3 \mathrm{~m}$. & $1 / 3$ & $2 / 3$ & 0.44843 \\
$\mathrm{Ti}$ & $2 d$ & $3 \mathrm{~m}$. & $1 / 3$ & $2 / 3$ & 0.69835 \\
$\mathrm{Au}$ & $2 c$ & $3 \mathrm{~m}$. & 0 & 0 & 0.09901 \\
$\mathrm{Au}$ & $2 c$ & $3 \mathrm{~m}$. & 0 & 0 & 0.40081 \\
$\mathrm{Au}$ & $2 d$ & $3 \mathrm{~m}$. & $1 / 3$ & $2 / 3$ & 0.15082 \\
$\mathrm{Au}$ & $2 d$ & $3 \mathrm{~m}$. & $1 / 3$ & $2 / 3$ & 0.34902 \\
$\mathrm{C}$ & $2 c$ & $3 \mathrm{~m}$. & 0 & 0 & 0.27820 \\
$\mathrm{C}$ & $2 d$ & $3 \mathrm{~m}$. & $1 / 3$ & $2 / 3$ & 0.02817 \\
$\mathrm{C}$ & $2 d$ & $3 \mathrm{~m}$. & $1 / 3$ & $2 / 3$ & 0.52817 \\
$\mathrm{C}$ & $2 d$ & $3 \mathrm{~m}$. & $1 / 3$ & $2 / 3$ & 0.77814 \\
\hline \hline
\end{tabular}

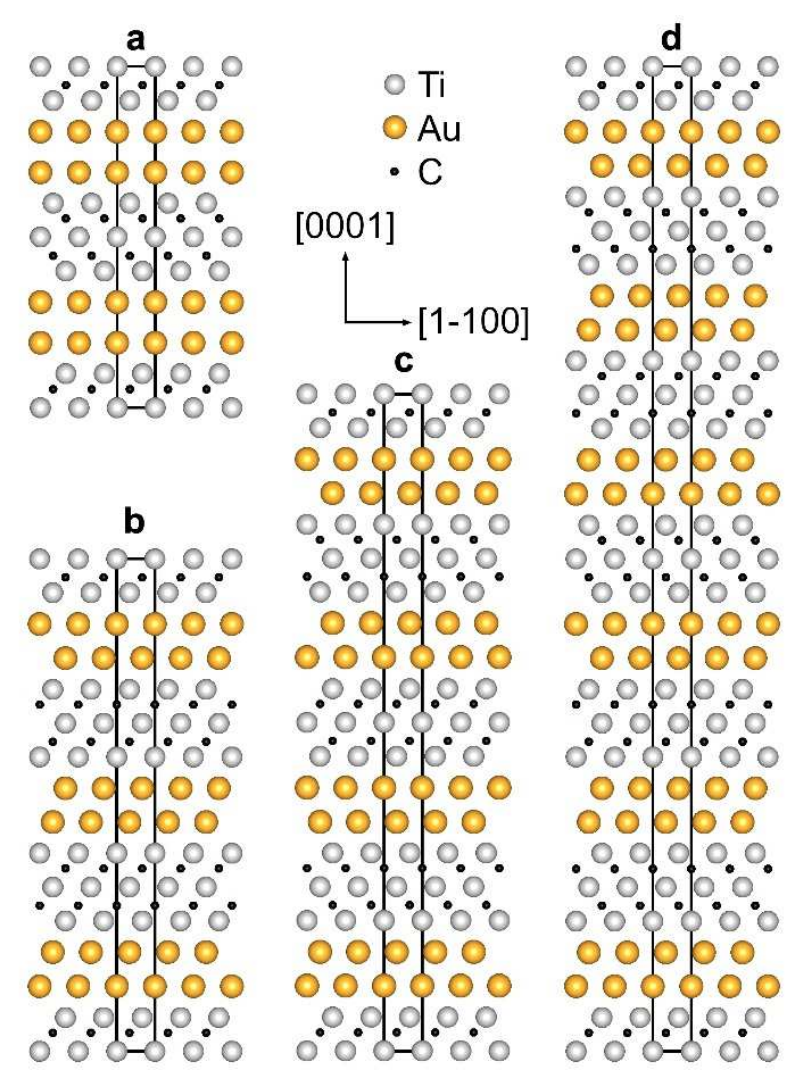

Figure S2. Schematic of $\mathrm{Ti}_{3} \mathrm{Au}_{2} \mathrm{C}_{2}$ crystal structure with different atomic stacking configurations of space group (a) $\mathrm{P}_{3} / \mathrm{mmc}$, (b) $\mathrm{P} 3 \mathrm{~m} 1$, (c) $\mathrm{P} \overline{3} \mathrm{~m} 1$, and (d) $\mathrm{R} \overline{3} \mathrm{~m}$.

\section{Section S4. Effect of annealing temperature on the transition from $\mathrm{Ti}_{3} \mathrm{SiC}_{2}$ to $\mathrm{Ti}_{3} \mathrm{AuC} \mathrm{C}_{2}$}


Figure $\mathrm{S} 3$ shows the XRD patterns for $\mathrm{Au} / \mathrm{Ti}_{3} \mathrm{SiC}_{2} / \mathrm{Au}$ samples annealed for $12 \mathrm{~h}$ at different temperatures. As can be seen, at $600{ }^{\circ} \mathrm{C}$ the 0001 peaks of $\mathrm{Ti}_{3} \mathrm{SiC}_{2}$ coexist with those of $\mathrm{Ti}_{3} \mathrm{AuC}_{2}$, but the former with considerably higher intensities that the latter. The intensity of the peaks for $\mathrm{Ti}_{3} \mathrm{AuC}_{2}$ gradually increases with rising the temperature and at $700{ }^{\circ} \mathrm{C}$ almost completely dominate those of $\mathrm{Ti}_{3} \mathrm{SiC}_{2}$.

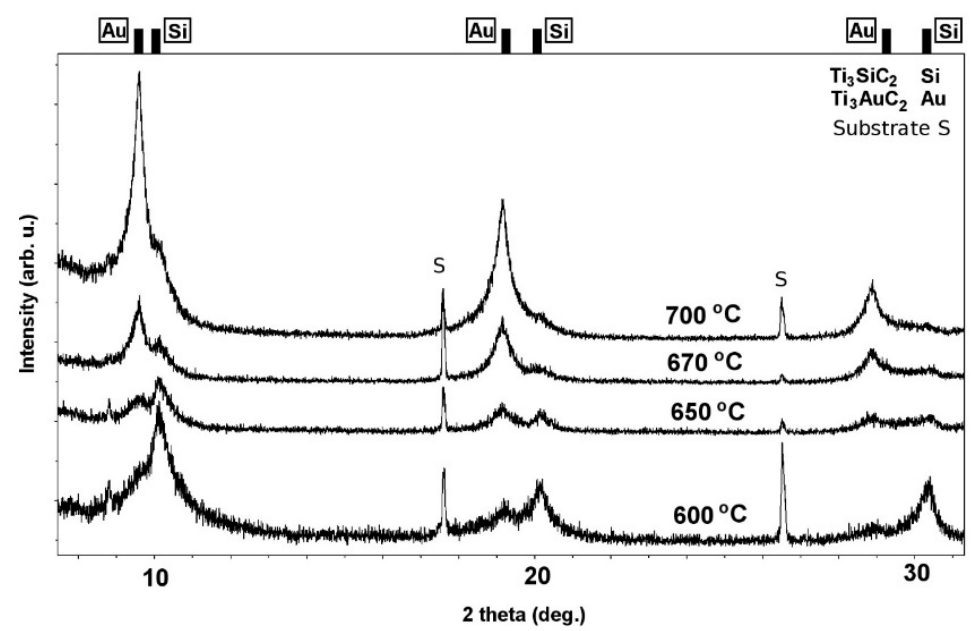

Figure S3. The effect of annealing temperature on the transition from $\mathrm{Ti}_{3} \mathrm{SiC}_{2}$ to $\mathrm{Ti}_{3} \mathrm{AuC}_{2}$. 
None of the considered $\operatorname{Ti}_{n+1} \operatorname{IrC}_{n}$ phases, with $n=1-3$, are found to be stable as seen in Table S3. Instead $\mathrm{TiC}$ and TiIr form, the $\mathrm{Ti}_{3} \mathrm{IrC}_{2}$ phase being metastable. This indicates that the formation of the $\mathrm{Ti}_{3} \mathrm{IrC}_{2}$ phase is likely supported by kinetic limitations.

Table S3. Calculated formation enthalpy and lattice parameters for $\operatorname{Ti}_{n+1} \operatorname{IrC}_{n}$, where $n=1,2$, 3.

\begin{tabular}{rcccc}
\hline Phase & $a(\AA)$ & $c(\AA)$ & $\Delta \mathrm{H}_{\mathrm{cp}}(\mathrm{meV} /$ atom $)$ & Competing phases \\
\hline $\mathrm{Ti}_{2} \mathrm{IrC}$ & 3.0513 & 12.815 & +127 & TiC, TiIr \\
$\mathrm{Ti}_{3} \mathrm{IrC}_{2}$ & 3.0452 & 17.967 & +52 & TiC, TiIr \\
$\mathrm{Ti}_{4} \mathrm{IrC}_{3}$ & 3.0157 & 23.523 & +42 & TiC, TiIr \\
\hline \hline
\end{tabular}




\section{Section S6. List of competing phases}

Table S4. Considered phases with their prototypical structure, calculated equilibrium volume per unit cell, lattice parameters and total energy.

\begin{tabular}{|c|c|c|c|c|c|c|c|c|}
\hline Phase & $\begin{array}{l}\text { Prototype } \\
\text { structure }\end{array}$ & $\begin{array}{l}\text { Pearson } \\
\text { symbol }\end{array}$ & Space group & $V\left(\AA^{3} / \mathbf{u c}\right)$ & $\mathbf{a}(\AA)$ & b (̊) & c $(\AA)$ & $E_{0}(e V / f . u)$. \\
\hline $\mathrm{Ti}$ & $\mathrm{Mg}$ & hP2 & $\mathrm{P} 63 / \mathrm{mmc}(194)$ & 34.24 & 2.924 & & 4.625 & -7.762 \\
\hline $\mathrm{Ti}$ & $\mathrm{Cu}$ & $\mathrm{cF} 4$ & Fm $\overline{3} m(225)$ & 17.10 & 4.090 & & & -7.706 \\
\hline $\mathrm{Ti}$ & W & $\mathrm{cI} 2$ & $\operatorname{Im} \overline{3} \mathrm{~m}(229)$ & 16.95 & 3.236 & & & -7.662 \\
\hline $\mathrm{Si}$ & $\mathrm{C}$ (diamond) & $\mathrm{cF} 8$ & $\mathrm{Fd} \overline{3} \mathrm{~m}(227)$ & 40.89 & 2.734 & & & -5.425 \\
\hline $\mathrm{Si}$ & & cP46 & & 1070.42 & 10.229 & & & -5.362 \\
\hline $\mathrm{Si}$ & & cI16 & & 147.56 & 6.658 & & & -5.267 \\
\hline $\mathrm{Au}$ & $\mathrm{Cu}$ & $\mathrm{cF} 4$ & Fm $\overline{3} \mathrm{~m}(225)$ & 71.83 & 4.157 & & & -3.220 \\
\hline Ir & $\mathrm{Cu}$ & $\mathrm{cF} 4$ & Fm $\overline{3} \mathrm{~m}(225)$ & 14.52 & 2.738 & & & -8.848 \\
\hline $\mathrm{C}$ & C (graphite) & $\mathrm{hP} 4$ & $\mathrm{P} 63 / \mathrm{mmc}(194)$ & 38.14 & 2.464 & & 7.250 & -9.225 \\
\hline $\mathrm{Ti}_{3} \mathrm{Si}$ & $\mathrm{Ti}_{3} \mathrm{P}$ & tP32 & $\mathrm{P} 42 / \mathrm{n} \mathrm{O} 2(86)$ & 518.88 & 10.126 & & 5.060 & -30.658 \\
\hline $\mathrm{Ti}_{5} \mathrm{Si}_{3}$ & $\mathrm{Mn}_{5} \mathrm{Si}_{3}$ & hP16 & $\mathrm{P} 63 / \mathrm{mcm}(193)$ & 246.59 & 7.467 & & 5.107 & -61.154 \\
\hline $\mathrm{Ti}_{5} \mathrm{Si}_{4}$ & $\mathrm{Zr}_{5} \mathrm{Si}_{4}$ & tP36 & $\mathrm{P} 4{ }_{12}{ }_{12}(92)$ & 547.25 & 6.703 & & 12.178 & -67.508 \\
\hline TiSi & $\mathrm{FeB}$ & oP8 & Pnma (62) & 119.09 & 6.523 & 3.643 & 5.012 & -14.704 \\
\hline $\mathrm{TiSi}_{2}$ & $\mathrm{ZrSi}_{2}$ & oC12 & Cmcm (63) & 89.97 & 3.540 & 13.562 & 3.581 & -20.289 \\
\hline $\mathrm{TiSi}_{2}$ & $\mathrm{TiSi}_{2}$ & $\mathrm{oF} 24$ & Fddd (70) & 84.91 & 8.258 & 4.802 & 8.564 & -20.265 \\
\hline $\mathrm{Ti}_{3} \mathrm{Au}$ & $\mathrm{Cr}_{3} \mathrm{Si}$ & cP8 & $\operatorname{Pm} \overline{3} n(223)$ & 131.73 & 5.088 & & & -27.998 \\
\hline $\mathrm{Ti}_{3} \mathrm{Au}$ & $\mathrm{Cu}_{3} \mathrm{Au}$ & $\mathrm{cP} 4$ & $\operatorname{Pm} \overline{3} \mathrm{~m}(221)$ & 66.86 & 4.059 & & & -27.459 \\
\hline TiAu (rt) & CuTi & $\mathrm{tP} 4$ & $\mathrm{P} 4 / \mathrm{nmm} \mathrm{O} 2$ (129) & 68.07 & 3.335 & & 6.119 & -11.840 \\
\hline TiAu (ht1) & $\mathrm{AuCd}$ & $\mathrm{oP} 4$ & Pmma (51) & 67.29 & 4.686 & 2.891 & 4.967 & -11.718 \\
\hline TiAu (ht2) & $\mathrm{CsCl}$ & $\mathrm{cP} 2$ & $\operatorname{Pm} \overline{3} \mathrm{~m}(221)$ & 34.48 & 3.255 & & & -11.571 \\
\hline $\mathrm{TiAu}_{2}$ & $\mathrm{MoSi}_{2}$ & tI6 & I4/mmm (139) & 102.53 & 3.460 & & 8.567 & -15.480 \\
\hline $\mathrm{TiAu}_{4}$ & $\mathrm{MoNi}_{4}$ & tI10 & $\mathrm{I} 4 / \mathrm{m}(87)$ & 172.95 & 6.577 & & 3.999 & -22.061 \\
\hline $\mathrm{Ti}_{3} \mathrm{Ir}$ & $\mathrm{Cr}_{3} \mathrm{Si}$ & $\mathrm{cP} 8$ & $\operatorname{Pm} \overline{3} n(223)$ & 124.79 & 4.997 & & & -34.461 \\
\hline $\mathrm{Ti}_{1.25} \operatorname{Ir}_{0.75}$ & $\mathrm{CsCl}$ & $\mathrm{cP} 2$ & $\operatorname{Pm} \overline{3} \mathrm{~m}(221)$ & 1944.4 & 3.120 & & & -17.754 \\
\hline Tilr & $\mathrm{CsCl}$ & $\mathrm{cP} 2$ & $\operatorname{Pm} \overline{3} \mathrm{~m}(221)$ & 30.21 & 3.114 & & & -18.112 \\
\hline TiIr & $\mathrm{AuCu}$ & tP4 & $\mathrm{P} 4 / \mathrm{mmm}$ (123) & 60.06 & 4.149 & & 3.490 & -18.281 \\
\hline TiIr3 & $\mathrm{Cu}_{3} \mathrm{Au}$ & $\mathrm{cP} 4$ & $\operatorname{Pm} \overline{3} \mathrm{~m}(221)$ & 58.07 & 3.872 & & & -37.138 \\
\hline $\mathrm{SiC}(6 \mathrm{H})$ & $6 \mathrm{H}-\mathrm{SiC}$ & hP12 & P63 mc (186) & 125.97 & 3.095 & & 15.186 & -15.065 \\
\hline$\beta-\mathrm{SiC}(3 \mathrm{C})$ & $\mathrm{ZnS}$ & $\mathrm{cF} 8$ & $\mathrm{~F} \overline{4} 3 \mathrm{~m}(216)$ & 84.01 & 4.380 & & & -15.064 \\
\hline $\mathrm{Ti}_{2} \mathrm{C}$ & $\mathrm{Ca}_{33} \mathrm{Ge}$ & $\mathrm{cF} 48$ & $\mathrm{Fd} \overline{3} \mathrm{~m}(227)$ & 161.16 & 8.639 & & & -26.583 \\
\hline $\mathrm{TiC}_{0.75}$ & $\mathrm{NaCl}$ & $\mathrm{cF} 8$ & Fm $\overline{3} \mathrm{~m}(225)$ & 81.13 & 4.329 & & & -15.961 \\
\hline $\mathrm{TiC}_{0.875}$ & $\mathrm{NaCl}$ & $\mathrm{cF} 8$ & Fm $\overline{3} \mathrm{~m}(225)$ & 162.7 & 4.333 & & & -17.263 \\
\hline $\mathrm{TiC}$ & $\mathrm{NaCl}$ & $\mathrm{cF} 8$ & $\mathrm{Fm} \overline{3} \mathrm{~m}(225)$ & 20.40 & 4.337 & & & -18.529 \\
\hline $\mathrm{TiC}$ & NiAs & $\mathrm{hP} 4$ & $\mathrm{P}_{3} / \mathrm{mmc}(194)$ & 40.83 & 3.164 & & 4.709 & -18.260 \\
\hline$\left(\mathrm{Ti}_{0.75} \mathrm{Si}_{0.25}\right) \mathrm{C}$ & $\mathrm{NaCl}$ & $\mathrm{cF} 8$ & Fmెㅡ (225) & 628.6 & 4.283 & & & -17.032 \\
\hline $\mathrm{Ti}_{5} \mathrm{Si}_{3} \mathrm{C}$ & $\mathrm{Mn}_{5} \mathrm{Si}_{3}$ & hP16 & $\mathrm{P} 63 / \mathrm{mcm}(193)$ & 249.40 & 7.475 & & 5.153 & -71.568 \\
\hline $\mathrm{Ti}_{5} \mathrm{Si}_{3} \mathrm{C}_{0.5}$ & $\mathrm{Mn}_{5} \mathrm{Si}_{3}$ & hP16 & $\mathrm{P}_{3} / \mathrm{mcm}(193)$ & 247.12 & 7.456 & & 5.133 & -66.618 \\
\hline $\mathrm{Ti}_{5} \mathrm{Si}_{3} \mathrm{C}_{0.5}$ & $\mathrm{Mn}_{5} \mathrm{Si}_{3}$ & hP16 & $\mathrm{P}_{3} / \mathrm{mcm}(193)$ & 494.58 & 7.454 & & 5.139 & -66.623 \\
\hline
\end{tabular}




\begin{tabular}{|c|c|c|c|c|c|c|c|}
\hline $\mathrm{Ti}_{5} \mathrm{Si}_{3} \mathrm{C}_{0.25}$ & $\mathrm{Mn}_{5} \mathrm{Si}_{3}$ & hP16 & $\mathrm{P}_{3} / \mathrm{mcm}(193)$ & 493.56 & 7.459 & 5.122 & -63.879 \\
\hline $\mathrm{Ti}_{2} \mathrm{SiC}$ & $\mathrm{Cr}_{2} \mathrm{AlC}$ & hP8 & $\mathrm{P}_{3} / \mathrm{mmc}(194)$ & 103.75 & 3.052 & 12.861 & -33.248 \\
\hline $\mathrm{Ti}_{3} \mathrm{SiC}_{2}$ & $\mathrm{Ti}_{3} \mathrm{SiC}_{2}$ & hP12 & $\mathrm{P}_{3} / \mathrm{mmc}(194)$ & 145.25 & 3.076 & 17.725 & -51.916 \\
\hline $\mathrm{Ti}_{4} \mathrm{SiC}_{3}$ & $\mathrm{Ti}_{4} \mathrm{AlN}_{3}$ & hP16 & $\mathrm{P}_{3} / \mathrm{mmc}(194)$ & 186.26 & 3.081 & 22.659 & -70.451 \\
\hline $\mathrm{Ti}_{5} \mathrm{SiC}_{4}$ & 514-MAX & hP20 & $\mathrm{P}_{3} / \mathrm{mmc}(194)$ & 227.1 & 3.080 & 27.633 & -88.956 \\
\hline $\mathrm{Ti}_{6} \mathrm{SiC}_{5}$ & 615-MAX & hP24 & $\mathrm{P}_{3} / \mathrm{mmc}(194)$ & 268.00 & 3.079 & 32.642 & -107.457 \\
\hline $\mathrm{Ti}_{5} \mathrm{Si}_{2} \mathrm{C}_{3}$ & "211+312" & hP20 & $\mathrm{P} 63 / \mathrm{mmc}(194)$ & 250.69 & 3.039 & 31.339 & -84.257 \\
\hline $\mathrm{Ti}_{5} \mathrm{Si}_{2} \mathrm{C}_{3}$ & "211+312" & hP30 & P3m1 (156) & 373.80 & 3.066 & 45.904 & -85.390 \\
\hline $\mathrm{Ti}_{5} \mathrm{Si}_{2} \mathrm{C}_{3}$ & "211+312" & hP30 & $\mathrm{R} \overline{3} \mathrm{~m}(166)$ & 373.74 & 3.069 & 45.814 & -85.171 \\
\hline $\mathrm{Ti}_{7} \mathrm{Si}_{2} \mathrm{C}_{5}$ & "312+413" & $\mathrm{hP} 42$ & P3m1 (156) & 497.21 & 3.078 & 60.583 & -122.429 \\
\hline $\mathrm{Ti}_{2} \mathrm{AuC}$ & $\mathrm{Cr}_{2} \mathrm{AlC}$ & hP8 & $\mathrm{P}_{3} / \mathrm{mmc}(194)$ & 112.07 & 3.069 & 13.742 & -30.451 \\
\hline $\mathrm{Ti}_{3} \mathrm{AuC}_{2}$ & $\mathrm{Ti}_{3} \mathrm{SiC}_{2}$ & $\mathrm{hP} 12$ & $\mathrm{P}_{3} / \mathrm{mmc}(194)$ & 153.61 & 3.085 & 18.638 & -49.172 \\
\hline $\mathrm{Ti}_{4} \mathrm{AuC}_{3}$ & $\mathrm{Ti}_{4} \mathrm{AlN}_{3}$ & hP16 & $\mathrm{P}_{3} / \mathrm{mmc}(194)$ & 194.65 & 3.087 & 23.584 & -67.708 \\
\hline $\mathrm{Ti}_{2} \mathrm{IrC}$ & $\mathrm{Cr}_{2} \mathrm{AlC}$ & hP8 & $\mathrm{P}_{3} / \mathrm{mmc}(194)$ & 103.33 & 3.051 & 12.815 & -36.302 \\
\hline $\mathrm{Ti}_{3} \mathrm{IrC}_{2}$ & $\mathrm{Ti}_{3} \mathrm{SiC}_{2}$ & hP12 & $\mathrm{P}_{3} / \mathrm{mmc}(194)$ & 144.29 & 3.045 & 17.967 & -55.028 \\
\hline $\mathrm{Ti}_{4} \mathrm{IrC}_{3}$ & $\mathrm{Ti}_{4} \mathrm{AlN}_{3}$ & hP16 & $\mathrm{P} 63 / \mathrm{mmc}(194)$ & 185.27 & 3.016 & 23.523 & -73.536 \\
\hline
\end{tabular}




\section{Section S7. Phonon dispersion plots}

Figure $\mathrm{S} 4$ shows phonon dispersion for four different crystal structures of $\mathrm{Ti}_{3} \mathrm{Au}_{2} \mathrm{C}_{2}$ in panel (a $-\mathrm{d}$ ), $\mathrm{Ti}_{3} \mathrm{AuC}_{2}$ in panel (e) and $\mathrm{Ti}_{3} \mathrm{IrC}_{2}$ in panel (f). All structures are found to be dynamically stable with the exception of $\mathrm{Ti}_{3} \mathrm{Au}_{2} \mathrm{C}_{2}$ in space group $\mathrm{P}_{3} / \mathrm{mmc}$ that exhibits imaginary frequencies at and near the $\Gamma$ and A high-symmetry points. For $\mathrm{Ti}_{3} \mathrm{AuC}_{2} \mathrm{P}_{3} / \mathrm{mmc}$ and $\mathrm{Ti}_{3} \mathrm{Au}_{2} \mathrm{C}_{2}$ $\mathrm{P} \overline{3} \mathrm{~m} 1$ spin-orbit coupling have been included with negligible effect on the phonon dispersion as compared to the case when spin-orbit coupling is not taken into account.
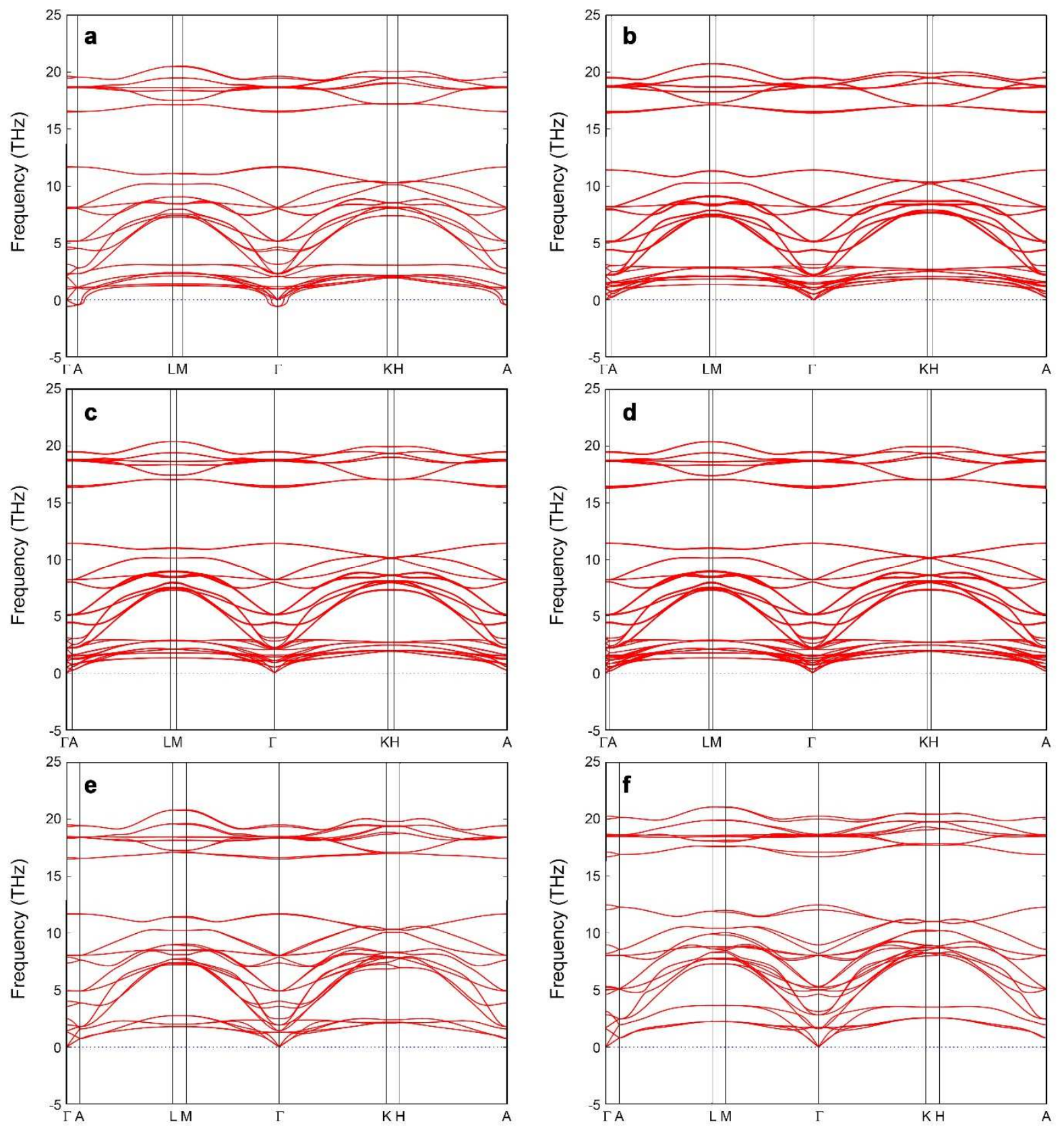

Figure S4. Phonon dispersion for (a) $\mathrm{Ti}_{3} \mathrm{Au}_{2} \mathrm{C}_{2} \mathrm{P} 6_{3} / \mathrm{mmc}$, (b) $\mathrm{Ti}_{3} \mathrm{Au}_{2} \mathrm{C}_{2} \mathrm{P} 3 \mathrm{ml}$, (c) $\mathrm{Ti}_{3} \mathrm{Au}_{2} \mathrm{C}_{2}$

$\mathrm{P} \overline{3} \mathrm{~m} 1$, (d) $\mathrm{Ti}_{3} \mathrm{Au}_{2} \mathrm{C}_{2} \mathrm{R} \overline{3} \mathrm{~m}$, (e) $\mathrm{Ti}_{3} \mathrm{AuC}_{2} \mathrm{P}_{3} / \mathrm{mmc}$, and (e) $\mathrm{Ti}_{3} \mathrm{IrC}_{2} \mathrm{P}_{3} / \mathrm{mmc}$. Schematic representation of $\mathrm{Ti}_{3} \mathrm{Au}_{2} \mathrm{C}_{2}$ structures $(\mathrm{a}-\mathrm{d})$ are depicted in Figure $\mathrm{S} 2(\mathrm{a}-\mathrm{d})$. The imaginary frequencies in optical phonon modes for $\mathrm{Ti}_{3} \mathrm{Au}_{2} \mathrm{C}_{2} \mathrm{P}_{3} / \mathrm{mmc}$ in panel (a) can be related to the the energetically unfavorable simple hexagonal arrangement of the Au bilayer. This is also reflected by its higher energy as compared to other Au bilayer arrangements, see Table S2. 


\section{Section S8. Details on the deposition of $\operatorname{IrO}_{x}$}

We deposited $\mathrm{IrO}_{\mathrm{x}}$ on $10 \times 10 \mathrm{~mm} \mathrm{Al}_{2} \mathrm{O}_{3}$ substrates with different partial pressures for $\mathrm{Ar}$ and $\mathrm{O}_{2}$ during the sputtering. The depositions were done at room-temperature. We chose 5, 10, 25, and $50 \%$ of $\mathrm{O}_{2}$ in $\mathrm{Ar}$ as the sputtering gas. The resistivity of the corresponding samples were measured using a Jandel four-point probe, as illustrated in Figure S5. As can be seen, the higher oxygen content resulted in the higher resistivity, although, the magnitude of the resistivity still remained low enough, typical of a metallic phase. We chose $25 \% \mathrm{O}_{2}$ for our main experiments regarding formation of oxidation barriers on ohmic contacts to $\mathrm{SiC}$, presented in the main article.

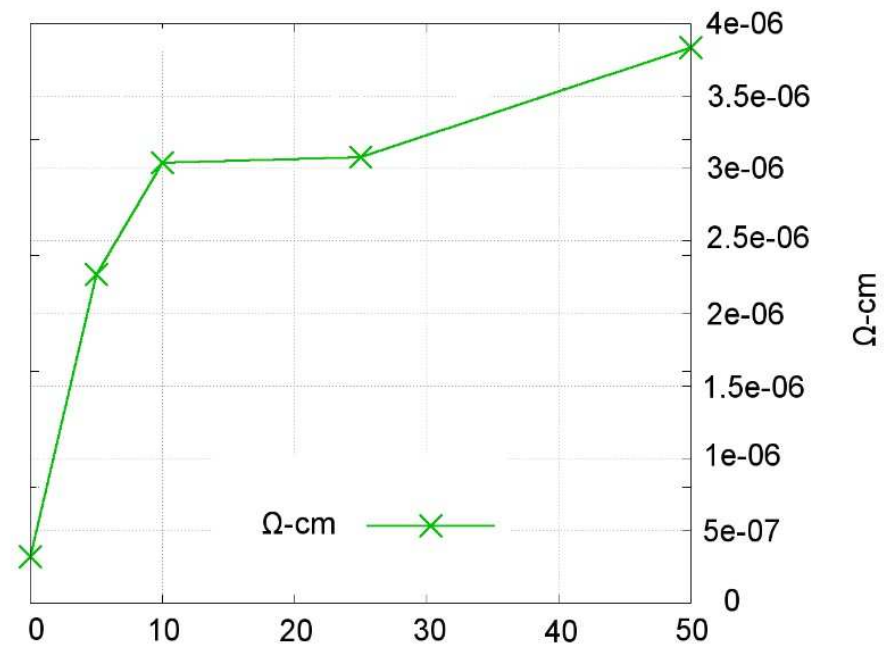

Partial pressure of $\mathrm{O}_{2} / \mathrm{Ar}$ during the reactive sputtering [\%]

Figure S5. Resistivity of $\mathrm{IrO}_{\mathrm{x}}$ films deposited with different oxygen to argon partial pressures. 


\section{Section S9. Inter-diffusion between Au and Ir and creation of voids}

Figure S.6 shows a low magnification STEM and EDX mapping of a specimen composed of two $\mathrm{Ir} / \mathrm{Au} / \mathrm{Ti}_{3} \mathrm{SiC}_{2} / \mathrm{SiC}$ samples, one fresh (bottom) and one with $12 \mathrm{~h}$ of annealing at $600^{\circ} \mathrm{C}$ (top). This was to ensure that the two experience the same conditions during the TEM sample preparation process. As can be seen, the fresh sample possess sharp borders at the Au/Ir interface, while for the annealed samples interdiffusion and creation of voids is clear. This would result in the structural degradation of the contact.

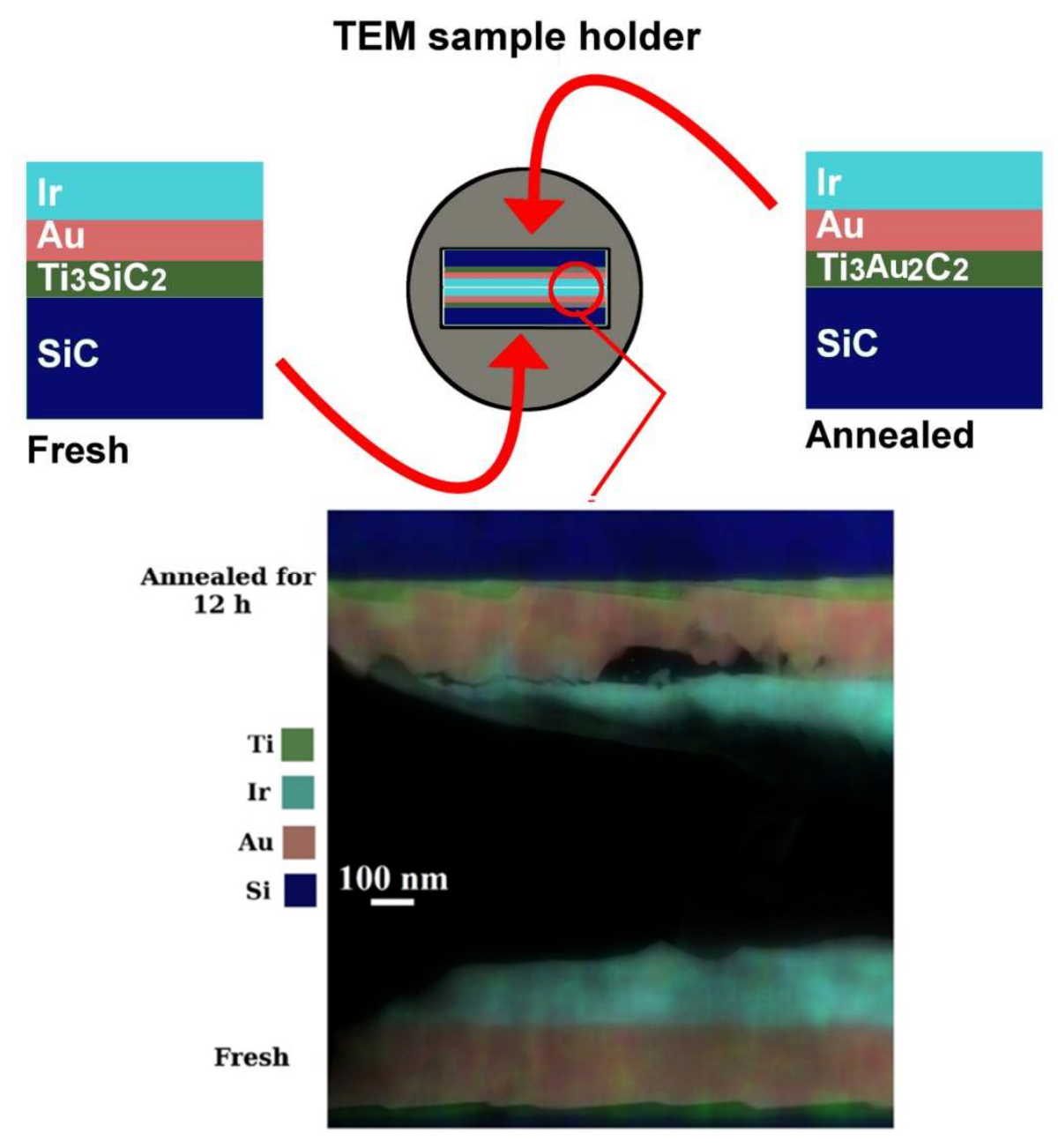

Figure S6. STEM and EDX of two $\mathrm{Ir} / \mathrm{Au} / \mathrm{Ti}_{3} \mathrm{SiC}_{2} / \mathrm{SiC}$ samples inserted into one specimen, one with $12 \mathrm{~h}$ of annealing at $600^{\circ} \mathrm{C}$ (transformed into $\mathrm{Ti}_{3} \mathrm{Au}_{2} \mathrm{C}_{2}$ ), and one as-deposited. 


\section{Section S10. Degradation of $\mathrm{IrO}_{\mathbf{x}} / \mathrm{Ti}_{3} \mathrm{SiC}_{2} / \mathrm{SiC}$ ohmic contacts in $600{ }^{\circ} \mathrm{C}$ air}

We studied the aging of $\mathrm{IrO}_{\mathrm{x}} / \mathrm{Ti}_{3} \mathrm{SiC}_{2} / \mathrm{SiC}$ ohmic contacts in which the only oxygen barrier was $\mathrm{IrO}_{\mathrm{x}}$ deposited directly on $\mathrm{Ti}_{3} \mathrm{SiC}_{2}$. We kept the sample in $600{ }^{\circ} \mathrm{C}$ air for 100 h. Fig. $\mathrm{S} 7$ (a) shows the XRD plot of the sample after the aging experiment while Fig.7 (b) demonstrates the I/V curve before and after the aging. As can be seen, the XRD plot shows no signs of 0001 $(1=2,4,6)$ diffraction peaks of $\mathrm{Ti}_{3} \mathrm{SiC}_{2}$ which appear approximately at $2 \theta^{\circ}=10^{\circ}, 20^{\circ}$, and $30^{\circ}$ (see Fig. $1 \mathrm{~h}$ in the main text). This corresponds to the destruction of the $\mathrm{Ti}_{3} \mathrm{SiC}_{2}$ phase during the aging process. This is confirmed by the I/V plot. The as-deposited sample shows an ohmic behavior while it acts as an open circuit, i.e., passing no current, after the aging, which corresponds to the complete destruction of the contact area of $\mathrm{Ti}_{3} \mathrm{SiC}_{2} / \mathrm{SiC}$. It should be mentioned that the $\mathrm{IrO}_{\mathrm{x}}$ peak appeared at about $28^{\circ}$ for the annealed sample is due to recrystallization caused during the annealing process at $600{ }^{\circ} \mathrm{C}$. We observed that peak for annealed $\mathrm{IrO}_{\mathrm{x}} / \mathrm{Al}_{2} \mathrm{O}_{3}$ samples as well which rules out its correspondence to any diffraction related to decomposed/oxidized $\mathrm{Ti}_{3} \mathrm{SiC}_{2}$, e.g., $\mathrm{TiO}_{2}$.
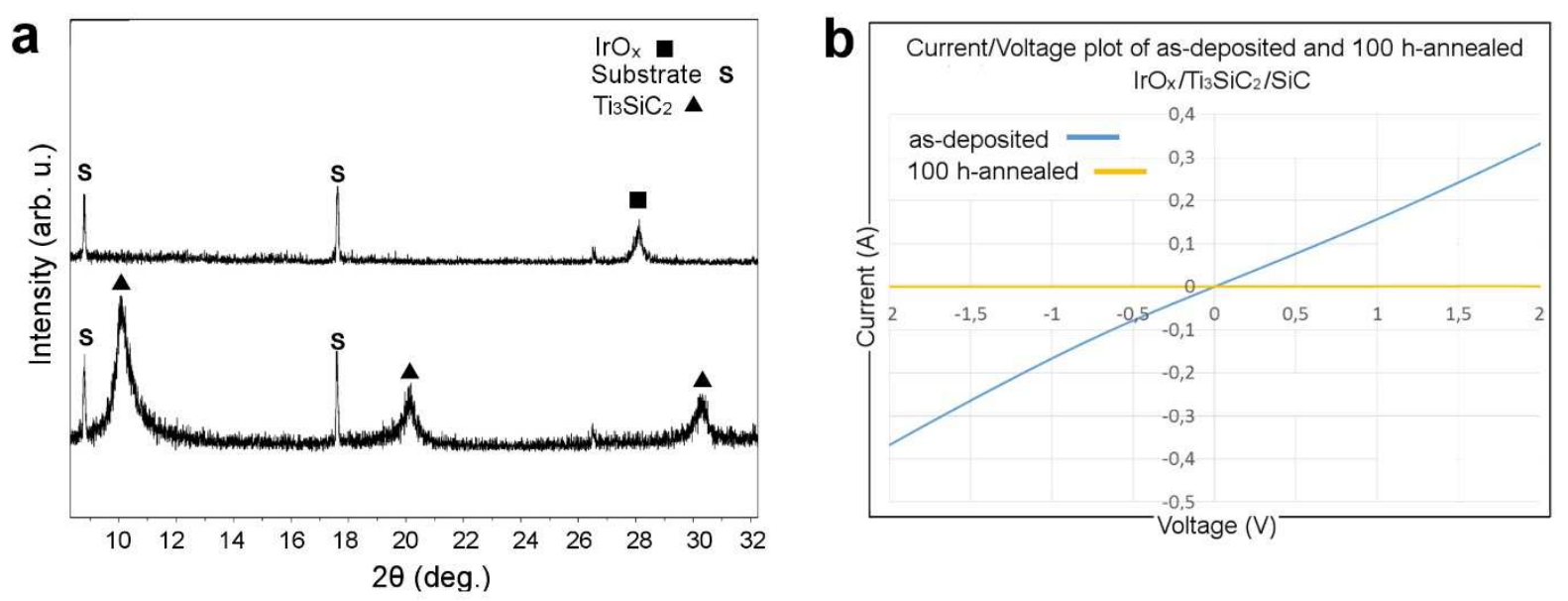

Figure S7. (a) XRD plot after the aging of $\mathrm{IrO}_{\mathrm{x}} / \mathrm{Ti}_{3} \mathrm{SiC}_{2} / \mathrm{SiC}$ for $100 \mathrm{~h}$ at $600{ }^{\circ} \mathrm{C}$ air. (b) $\mathrm{The}$ $\mathrm{I} / \mathrm{V}$ curve before and after the aging experiment. 


\section{Section S11. Stacking faults in Au-layers.}

As discussed in the main text with respect to Fig.2, irregularities in the Au-containing regions can be observed. A possible reason for that can be the presence of stacking faults in the structure of $\mathrm{Ti}_{3} \mathrm{SiC}_{2}$ host. Fig. S8 shows an overview image of partially formed $\mathrm{Ti}_{3} \mathrm{AuC}_{2}$ in which two distinct four-layer thick A-layers can be observed. Considering the atomic stacking of the $\mathrm{Ti}_{3} \mathrm{C}_{2}$ layers, it can be seen that each of those two four-atom thick Au layers are followed by stacking faults in the adjacent $\mathrm{Ti}_{3} \mathrm{C}_{2}$ layers marked by red a and $\mathrm{b}$ signs in the figure.

Fig. S9 is a STEM image from two different crystal orientations of another site $\mathrm{Ti}_{3} \mathrm{SiC}_{2}$ after the introduction of Au. Similar to Fig. S8, Fig. S9 shows irregularities within Au-containing regions as a result of stacking faults within $\mathrm{Ti}_{3} \mathrm{SiC}_{2}$. Au atoms are seen on inclined lattice planes forming ladders between the basal planes of the MAX structure [see Fig S9(a)].

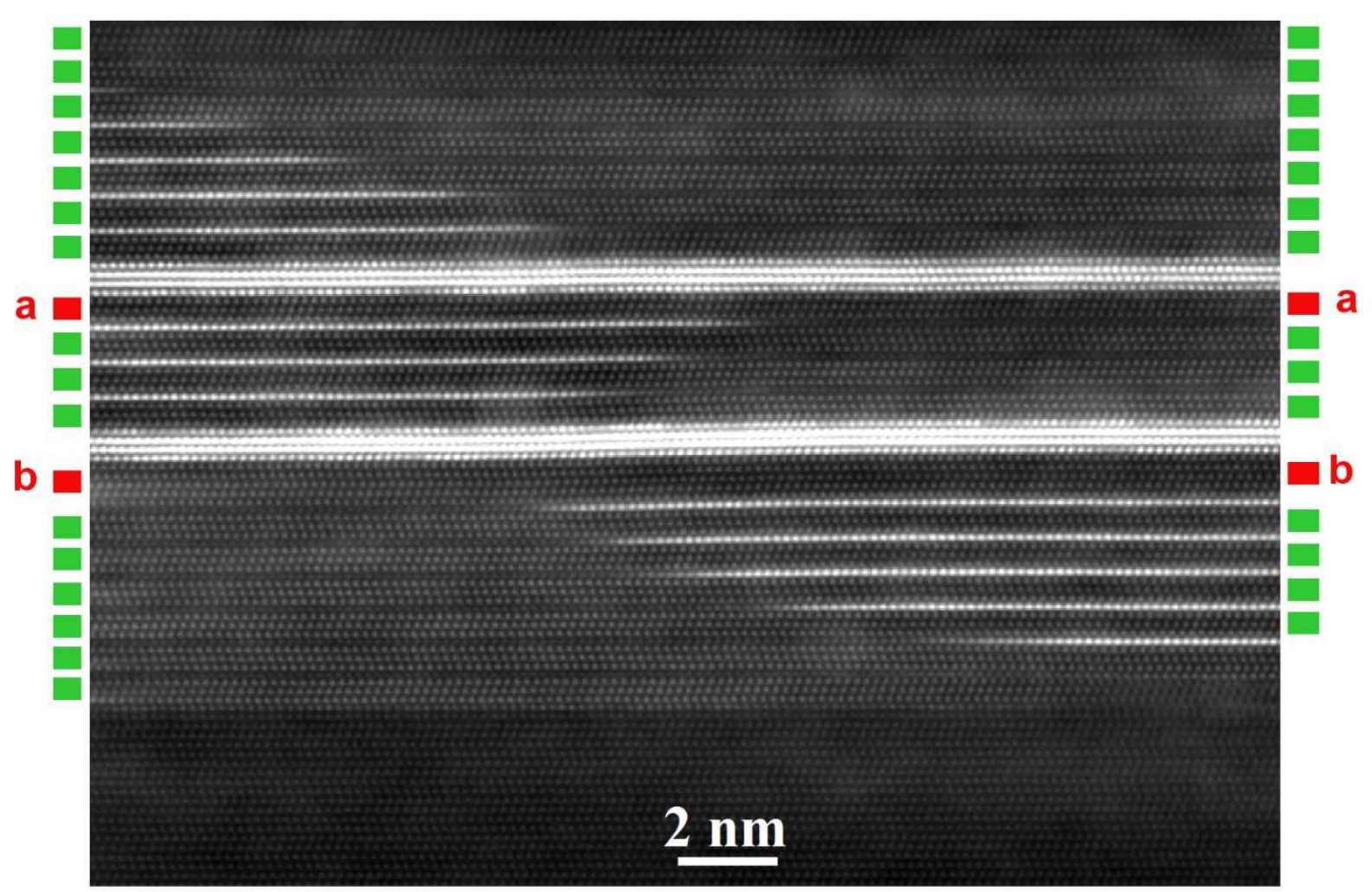

Figure S8. Stacking faults in $\mathrm{Ti}_{3} \mathrm{SiC}_{2}$ and its influence on the order of the introduction of $\mathrm{Au}$ in $\mathrm{Ti}_{3} \mathrm{SiC}_{2}$. On the sides of the image, the ordered stackings are marked with green boxes while red boxes refer to stacking faults within the crystal of $\mathrm{Ti}_{3} \mathrm{SiC}_{2}$. Red boxes (a) and (b) refer to an inclination fault and the existence of two extra Ti layers (or the absence of a Si

layer), respectively." 


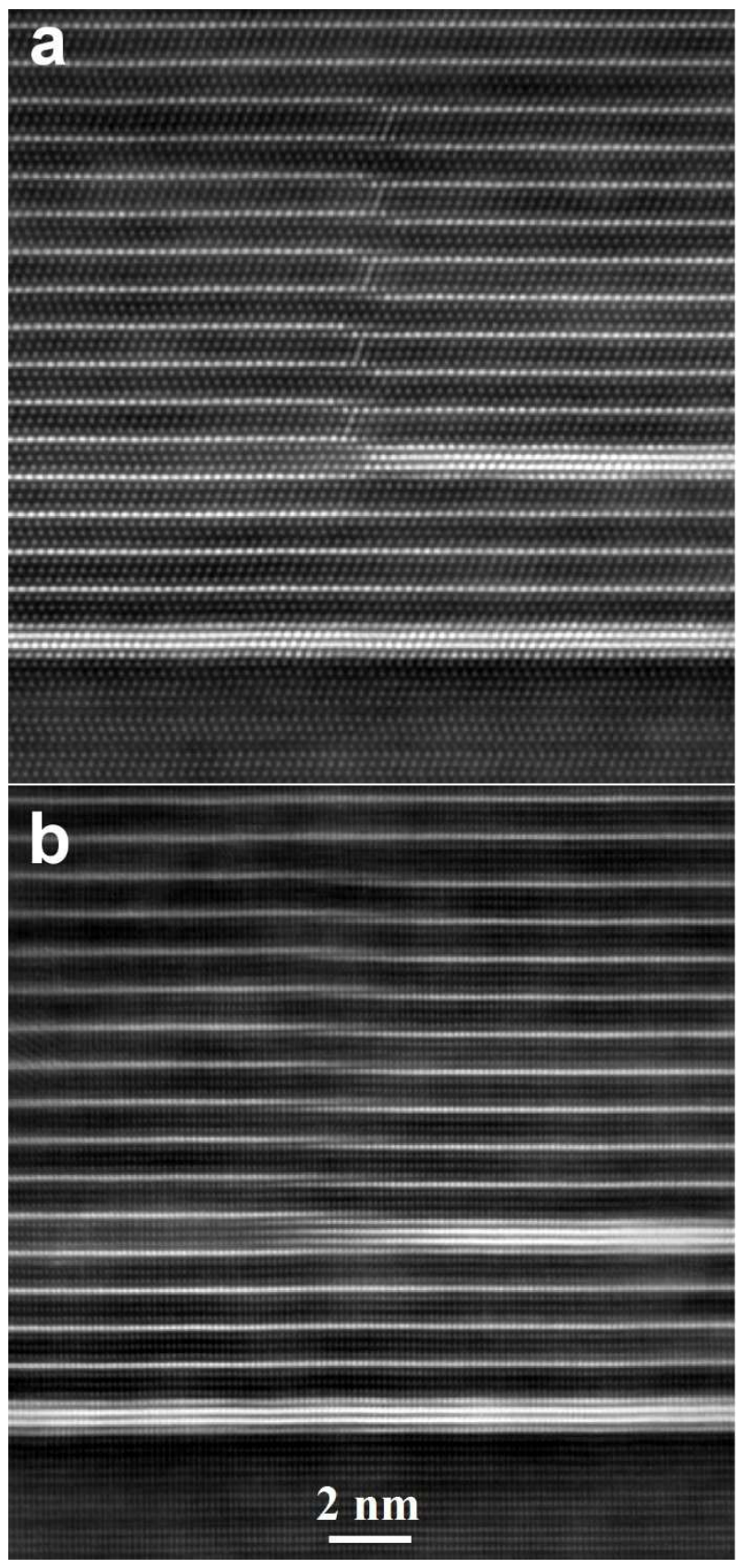

Figure S9. (a) and (b) STEM images of Au-introduction into $\mathrm{Ti}_{3} \mathrm{SiC}_{2}$ in the same region but viewed through two different directions, [11 $\overline{2} 0]$ and [1 $1 \overline{1} 00]$ for (a) and (b), respectively. Stacking faults for $\mathrm{Ti}_{3} \mathrm{C}_{2}$ layers has resulted in irregularities for the $\mathrm{Au}$-containing layers. 


\section{Section S12. Chemical bonding}

We performed electron energy loss spectroscopy (EELS) in order to gain understanding about the chemical bonding of the noble metals in these layered structures. Fig. S10. (a,b, and c) show the EELS spectra of the noble metals in $\mathrm{Ti}_{3} \mathrm{AuC}_{2}, \mathrm{Ti}_{3} \mathrm{Au}_{2} \mathrm{C}_{2}$, and $\mathrm{Ti}_{3} \mathrm{IrC}_{2}$, respectively. Each spectrum is plotted together with that of the corresponding pure noble metal so that any differences between the two with regard to the oxidation states can be revealed. This facilitates identifying the oxidation states of the noble metals. ${ }^{14,15}$ As can be seen, no distinctive shift can be observed between the EELS spectrum of the noble metals in the $\mathrm{Ti}_{3} \mathrm{AuC}_{2}, \mathrm{Ti}_{3} \mathrm{Au}_{2} \mathrm{C}_{2}$, and $\mathrm{Ti}_{3} \mathrm{IrC}_{2}$ phases when compared to those of their pure elemental state. In addition, the near-edge fine structure of the peaks are rather identical. These findings indicate a zero (or near-zero) valence state for the noble metals whose bonding state are seemingly of covalent/metallic nature.

Fig. S11. illustrates total and partial electronic density of states (DOS) and projected crystal orbital Hamiltonian populations (pCOHP) of $\mathrm{Ti}_{3} \mathrm{SiC}_{2}$ as well as those of $\mathrm{Ti}_{3} \mathrm{AuC}_{2}, \mathrm{Ti}_{3} \mathrm{Au}_{2} \mathrm{C}_{2}$, and $\mathrm{Ti}_{3} \mathrm{IrC}_{2}$. DOS and pCOHP of $\mathrm{Ti}_{3} \mathrm{SiC}_{2}$ (Fig.S.11 (a)), show clear bonding of Ti-C and Ti-Si. Replacing Si with $\mathrm{Au}$ in $\mathrm{Ti}_{3} \mathrm{AuC}_{2}$ (Fig.S.11 (b)), the Au states are shifted down in energy as compared to $\mathrm{Si}$. The Ti-Au do show bonding character but not as strong as $\mathrm{Ti}-\mathrm{Si}$ in $\mathrm{Ti}_{3} \mathrm{SiC}_{2}$ as is indicated by smaller integrated pCOHP (IpCOHP) of $-1.22 \mathrm{eV} /$ bond for Ti-Au viz. 1.82 $\mathrm{eV} /$ bond for Ti-Si. $\mathrm{Ti}_{3} \mathrm{Au}_{2} \mathrm{C}_{2}$ (Fig.S.11 (c)) show many similarities with $\mathrm{Ti}_{3} \mathrm{AuC}_{2}$ with strong Ti-C bonds and weaker Ti-Au bonds. The Au-Au interaction show both bonding and antibonding character between -8 and $-2 \mathrm{eV}$. For the case of $\mathrm{Ti}_{3} \operatorname{IrC}_{2}$ (Fig.S.11 (d)), the corresponding DOS plot shows rather high densities for Ir as well as Ti(4f) atoms at $\approx 2-5 \mathrm{eV}$ below the Fermi level. The corresponding pCOHP plot reveals the densities to form comparatively strong Ti-Ir bonding states with IpCOHP $=1.88 \mathrm{eV} /$ bond.

a

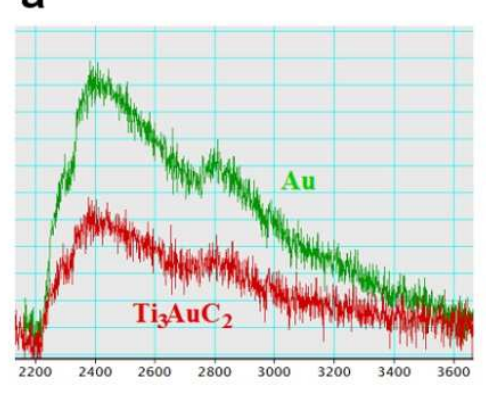

b

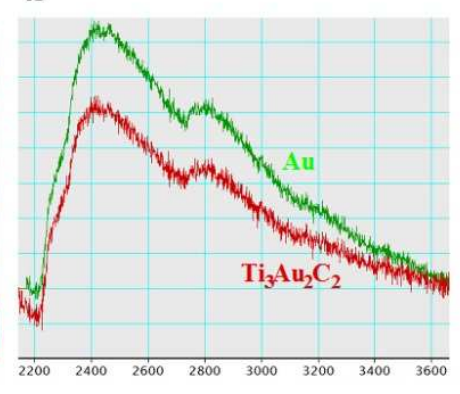

C

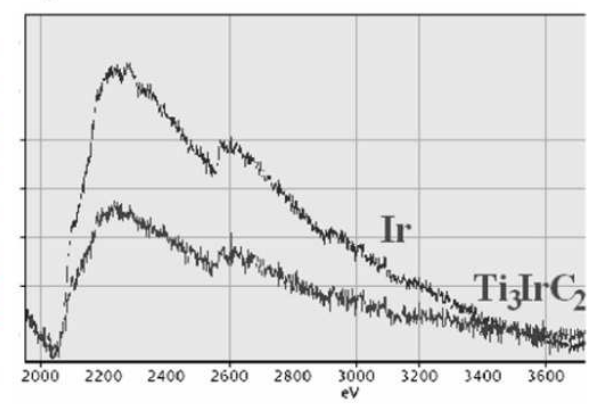

Figure S10. (a,b, and c) the EELS spectra of the noble metals in $\mathrm{Ti}_{3} \mathrm{AuC}_{2}, \mathrm{Ti}_{3} \mathrm{Au}_{2} \mathrm{C}_{2}$, and $\mathrm{Ti}_{3} \mathrm{IrC}_{2}$, respectively, together with that of the corresponding pure noble metal. 
$E-E_{f}(e V)$


$E_{-}-E_{f}(e V)$
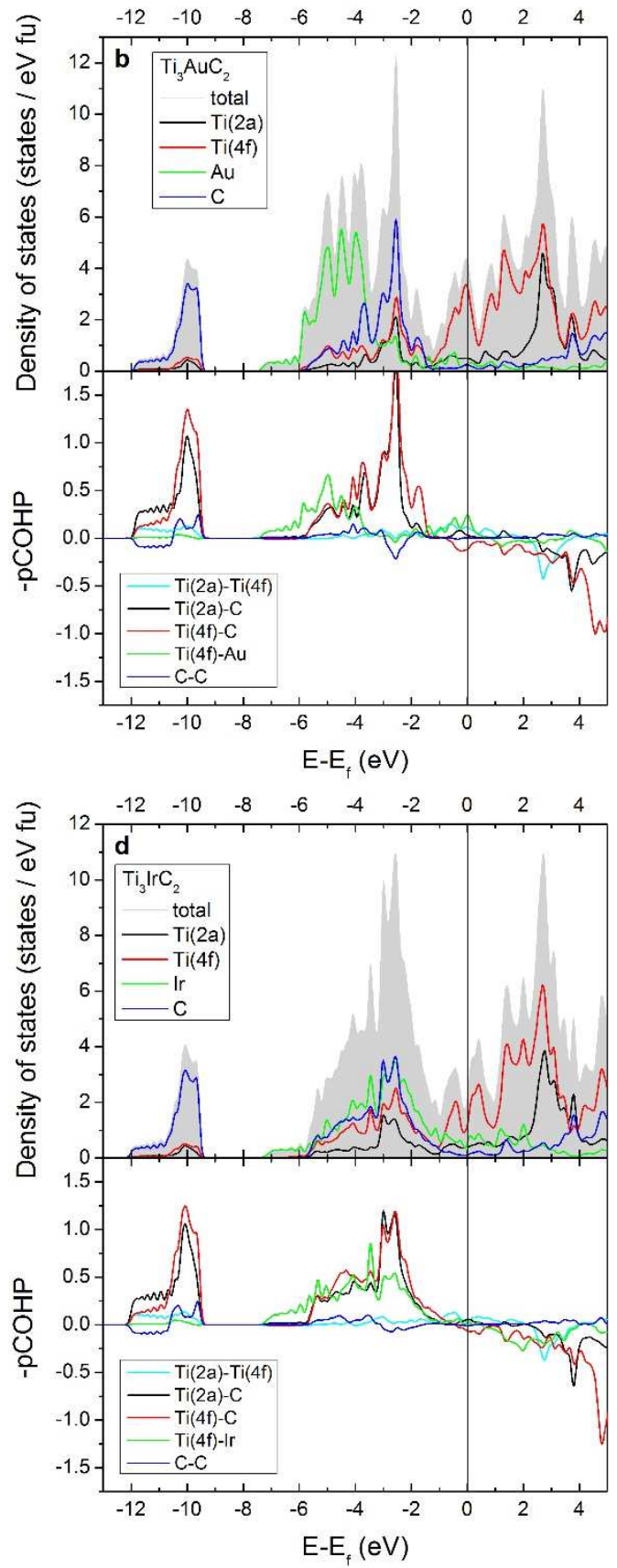

Figure S11. Calculated total and partial density of states DOS (top panel) and projected crystal orbital Hamiltonian populations pCOHP (bottom panel) for (a) $\mathrm{Ti}_{3} \mathrm{SiC}_{2} \mathrm{P}_{3} / \mathrm{mmc}$, (b) $\mathrm{Ti}_{3} \mathrm{AuC}_{2} \mathrm{P}_{3} / \mathrm{mmc}$, (c) $\mathrm{Ti}_{3} \mathrm{Au}_{2} \mathrm{C}_{2} \mathrm{P}-3 \mathrm{~m} 1$, and (d) $\mathrm{Ti}_{3} \mathrm{IrC}_{2} \mathrm{P} 6_{3} / \mathrm{mmc}$. Both DOS and pCOHP are obtained using the LOBSTER program. 


\section{Section S13. Electronic band structure}

In Fig. S12 the electronic band structure is shown for $\mathrm{Ti}_{3} \mathrm{SiC}_{2}, \mathrm{Ti}_{3} \mathrm{AuC}_{2}, \mathrm{Ti}_{3} \mathrm{Au}_{2} \mathrm{C}_{2} \mathrm{P}-3 \mathrm{~m} 1$, and $\mathrm{Ti}_{3} \mathrm{IrC}_{2}$ without spin-orbit coupling (black lines) and with spin-orbit coupling (red lines). Including spin-orbit coupling mostly affects bands around -6 to $-4 \mathrm{eV}$ below the Fermi level $\left(\mathrm{E}_{\mathrm{f}}\right)$ where the majority of the $\mathrm{Au}$ and Ir states are found but also bands at or close to $\mathrm{E}_{\mathrm{f}}$.
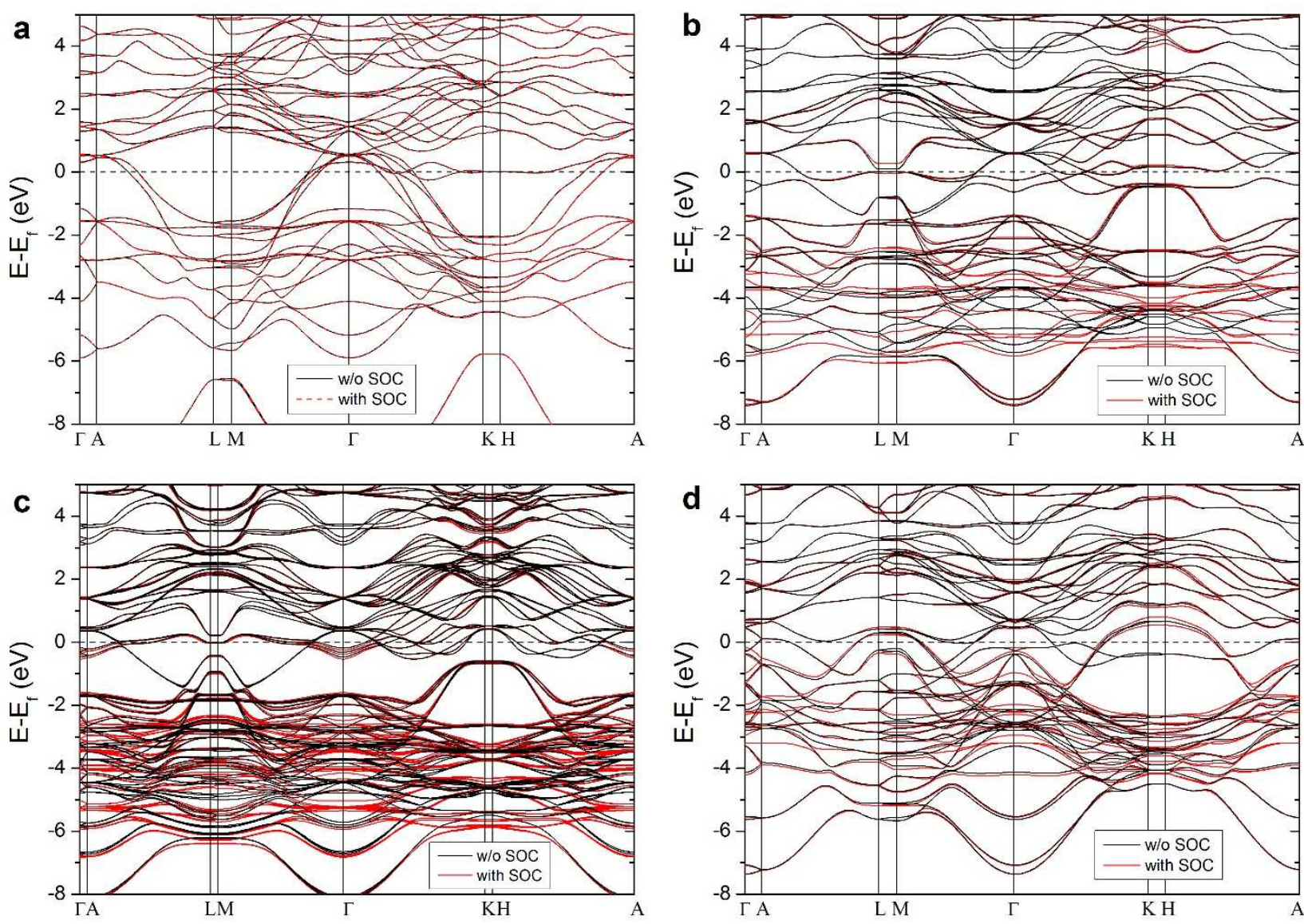

Figure S12. Calculated electronic band structure without spin-orbit coupling (black lines) and with spin-orbit coupling (red lines) for (a) $\mathrm{Ti}_{3} \mathrm{SiC}_{2} \mathrm{P} 6_{3} / \mathrm{mmc}$, (b) $\mathrm{Ti}_{3} \mathrm{AuC}_{2} \mathrm{P}_{3} / \mathrm{mmc}$, (c) $\mathrm{Ti}_{3} \mathrm{Au}_{2} \mathrm{C}_{2} \mathrm{P}-3 \mathrm{~m} 1$, and (d) $\mathrm{Ti}_{3} \mathrm{IrC}_{2} \mathrm{P} 6_{3} / \mathrm{mmc}$. Au- and Ir-based phases show differences in their electronic band structure when the spin-orbit coupling is considered, see e.g. band splitting at the Fermi level $\mathrm{E}_{\mathrm{f}}$ and $\mathrm{L}-\mathrm{M}$ for Ti3AuC2. For $\mathrm{Ti}_{3} \mathrm{SiC}_{2}$, the spin-orbit coupling does not influence the electronic band structure. 


\section{Section S14. In-situ annealing in TEM}

\section{In-situ TEM study details}

We applied high-resolution in-situ scanning transmission electron microscopy (STEM) to directly visualize the reaction introducing $\mathrm{Au}$ into $\mathrm{Ti}_{3} \mathrm{SiC}_{2}$ during heating. The in-situ heating experiments were performed in the double-corrected Linköping FEI Titan ${ }^{3} 60-300$ operated at $300 \mathrm{kV}$, using a MEMS-based double-tilt heating system (DENSsolutions). TEM samples for in-situ investigation were prepared from the as-synthesized structure $\left(\mathrm{Au} / \mathrm{Ti}_{3} \mathrm{SiC}_{2} / \mathrm{SiC}\right)$ using the Focused Ion Beam (FIB) lift-out procedure adopted from Duchamp et al. ${ }^{14}$ The in-situ heating started by pre-heating the sample at $400{ }^{\circ} \mathrm{C}$ for $10 \mathrm{~min}$, then continuously heating at $450{ }^{\circ} \mathrm{C}$ for $4 \mathrm{~h}$. The need for the temperature adjustment with respect to bulk sample heating is because of the TEM geometry where the surface-to-volume ratio is higher. While heating, atomic-resolution STEM high-angle annular dark-field (STEM-HAADF) imaging was carried out using $21.5 \mathrm{mrad}$ convergence angle probe carrying $50 \mathrm{pA}$ current and inner angle of the HAADF detector was set to $40 \mathrm{mrad}$. STEM-HAADF images were acquired at a frame time of 5 s (image size 1024 px x 1024 px). A series of high-resolution STEM-HAADF images were recorded at representative 3 min time intervals, which were used for constructing the movie.

\section{Movie}

The in-situ STEM movie (provided as Supplementary video) reveals changes in the STEM image contrast. The imaging conditions promote strong image contrast dependence on atomic number $\mathrm{Z}$. The appearing bright contrast features corresponds to the introduction of $\mathrm{Au}$ atoms into the $\mathrm{Ti}_{3} \mathrm{SiC}_{2}$ film. Initially $\mathrm{Au}$ was introduced at the top of the $\mathrm{Ti}_{3} \mathrm{SiC}_{2}$ film (at $\mathrm{Au} / \mathrm{Ti}_{3} \mathrm{SiC}_{2}$ interface) while in the end (from $201 \mathrm{~min}$ ), Au moved into the film from the right side which was the faster diffusion path because of sample geometry.

Movie caption. STEM movie showing the reaction process from $\mathrm{Ti}_{3} \mathrm{SiC}_{2}$ to $\mathrm{Ti}_{3} \mathrm{AuC}_{2}$ in situ. 


\section{Section S15: Electrical characteristics of the ohmic contacts over time}

Figures S.13 and S.14 show the I/V curves and the corresponding electrical resistance of the $\mathrm{IrO}_{\mathrm{x}} / \mathrm{Au} / \mathrm{Ti}_{3} \mathrm{SiC}_{2} / \mathrm{SiC}$ sample over the aging experiments, respectively. As can be seen, the ohmicity of the sample remains intact over the 1000-h aging experiment, i.e., the linearity of the curves are not affected. In addition, the slope of the I/V curves increases over time; that is, the resistance decreases (after an initial run-in) during the aging experiment (Fig. S14). This decrease was also observed for the $\mathrm{Ir} / \mathrm{Au} / \mathrm{Ti}_{3} \mathrm{SiC}_{2} / \mathrm{SiC}$ sample and is expected as the high annealing temperature, $600{ }^{\circ} \mathrm{C}$, in the absence of any oxidation or interdiffusion results in the increase of interface ordering and progress of the intercalation process, which both improve the electrical properties.

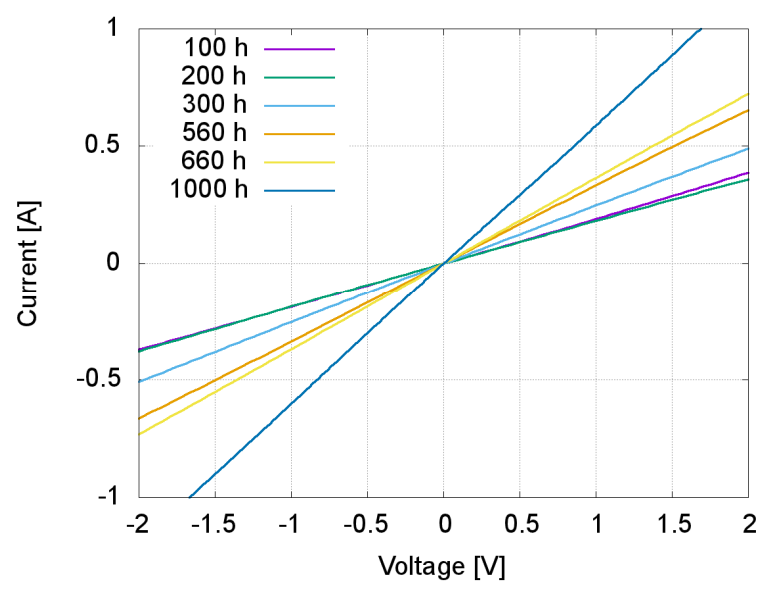

Figure S13. I/V curves for different time of annealing in $600{ }^{\circ} \mathrm{C}$ air.

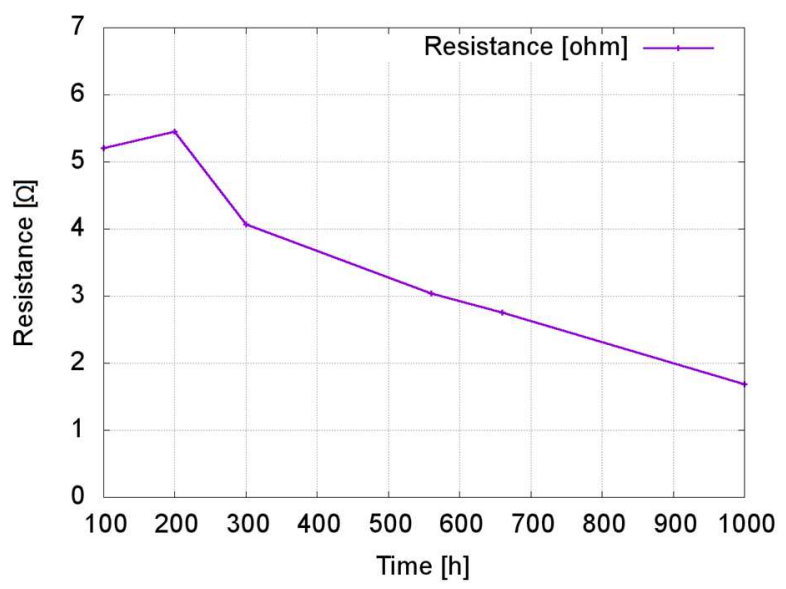

Figure S14. Resistance vs. aging time. 


\section{References}

1. Blöchl, P. E. Projector augmented-wave method. Phys. Rev. B 50, 17953-17979 (1994).

2. Kresse, G, D. J. From ultrasoft pseudopotentials to the projector augmented-wave method. Phys. Rev. B 59, 1758-1775 (1999).

3. Kresse, G. \& Hafner, J. Ab initio molecular dynamics for liquid metals. Phys. Rev. B 47, 558-561 (1993).

4. Kresse, G. \& Furthmüller, J. Efficiency of ab-initio total energy calculations for metals and semiconductors using a plane-wave basis set. Comput. Mater. Sci. 6, 15-50 (1996).

5. Kresse, G. Efficient iterative schemes for ab initio total-energy calculations using a plane-wave basis set. Phys. Rev. B 54, 11169-11186 (1996).

6. Perdew, J. P., Burke, K. \& Ernzerhof, M. Generalized Gradient Approximation Made Simple. Phys. Rev. Lett. 77, 3865-3868 (1996).

7. Hobbs, D., Kresse, G. \& Hafner, J. Fully unconstrained noncollinear magnetism within the projector augmented-wave method. Phys. Rev. B 62, 11556-11570 (2000).

8. Marsman, M. \& Hafner, J. Broken symmetries in the crystalline and magnetic structures of $\gamma$-iron. Phys. Rev. B 66, 224409 (2002).

9. Dronskowski, R. \& Bloechl, P. E. Crystal orbital Hamilton populations (COHP): energy-resolved visualization of chemical bonding in solids based on densityfunctional calculations. J. Phys. Chem. 97, 8617-8624 (1993).

10. Dahlqvist, M., Alling, B., Abrikosov, I. A. \& Rosén, J. Phase stability of Ti2AlC upon oxygen incorporation: A first-principles investigation. Phys. Rev. B 81, 24111 (2010).

11. Dahlqvist, M., Alling, B. \& Rosén, J. Stability trends of M A X phases from first principles. Phys. Rev. B 81, 220102 (2010).

12. Deringer, V. L., Tchougréeff, A. L. \& Dronskowski, R. Crystal orbital Hamilton population (COHP) analysis as projected from plane-wave basis sets. J. Phys. Chem. A 115, 5461-6 (2011).

13. Maintz, S., Deringer, V. L., Tchougréeff, A. L. \& Dronskowski, R. Analytic projection from plane-wave and PAW wavefunctions and application to chemical-bonding analysis in solids. J. Comput. Chem. 34, 2557-67 (2013).

14. Egerton, R. F. Electron energy-loss spectroscopy in the TEM. Reports Prog. Phys. 72, 16502 (2009).

15. Koski, K. J. et al. High-density chemical intercalation of zero-valent copper into Bi2Se3 nanoribbons. J. Am. Chem. Soc. 134, 7584-7 (2012).

14. Duchamp, M., Xu, Q. \& Dunin-Borkowski, R. E. Convenient preparation of highquality specimens for annealing experiments in the transmission electron microscope. Microsc. Microanal. 20, 1638-1645 (2014) 